\title{
Standard methods for American foulbrood research
}

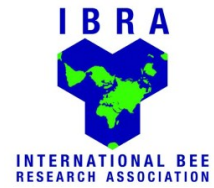

\section{Dirk C de Graaf ${ }^{1 *}$, Adriana M Alippi ${ }^{2}$, Karina Antúnez ${ }^{3}$, Katherine A Aronstein ${ }^{4}$, Giles Budge ${ }^{5}$, Dieter De Koker $^{1}$, Lina De Smet ${ }^{1}$, Douglas W Dingman ${ }^{6}$, Jay D Evans ${ }^{7}$, Leonard J Foster ${ }^{8}$, Anne Fünfhaus ${ }^{9}$, Eva Garcia-Gonzalez ${ }^{9}$, Aleš Gregorc ${ }^{10}$, Hannelie Human ${ }^{11}$, K Daniel Murray ${ }^{12}$, Bach Kim Nguyen ${ }^{13}$, Lena Poppinga ${ }^{9}$, Marla Spivak ${ }^{14}$, Dennis vanEngelsdorp ${ }^{15}$, Selwyn Wilkins ${ }^{5}$ and Elke Genersch ${ }^{9}$}

${ }^{1}$ Ghent University, Laboratory of Zoophysiology, K.L. Ledeganckstraat 35, B-9000 Ghent, Belgium.

${ }^{2}$ Universidad Nacional de La Plata, Facultad de Ciencias Agrarias y Forestales, Centro de Investigaciones de Fitopatología, calles 60 y 118, c.c. 31, 1900 La Plata, Argentina.

${ }^{3}$ Instituto de Investigaciones Biológicas Clemente Estable, Department of Microbiology, Avda. Italia 3318, 11600 Montevideo, Uruguay.

${ }^{4}$ USDA-ARS, Honey Bee Research Unit, Kika de la Garza Subtropical Agricultural Center, 2413 E. Hwy 83, 78596 Weslaco TX, USA.

${ }^{5}$ National Bee Unit, Food and Environment Research Agency, Sand Hutton, YO41 1LZ York, UK.

${ }^{6}$ The Connecticut Agricultural Experiment Station, Department of Biochemistry and Genetics, New Haven CT 06504, USA.

${ }^{7}$ USDA-ARS, Bee Research Lab, BARC-E Bldg 476, Beltsville MD 20705, USA.

${ }^{8}$ University of British Columbia, Department of Biochemistry \& Molecular Biology, 2125 East Mall, V6T 1Z4 Vancouver BC, Canada.

${ }^{9}$ Institute for Bee Research, Friedrich-Engels-Str. 32, 16540 Hohen Neuendorf, Germany.

${ }^{10}$ Agricultural Institute of Slovenia, Hacquetova 17, 1000 Ljubljana, Slovenia.

${ }^{11}$ University of Pretoria, Department of Zoology and Entomology, Pretoria, South Africa.

${ }^{12}$ South Texas College, Biology Department, 400 N. Border, 78596 Weslaco TX, USA.

${ }^{13}$ Université de Liège, Gembloux Agro-Bio Tech, Entomologie fonctionnelle \& évolutive, Passage des Déportés 2, B-5030 Gembloux, Belgium.

${ }^{14}$ University of Minnesota, Department of Entomology, 219 Hodson Hall, 1980 Folwell Ave., 55108 St. Paul MN, USA.

${ }^{15}$ University of Maryland, Department of Entomology, 3136 Plant Sciences, College Park, MD 20742, USA

$\S$ in memoriam: July 24, 1987 - † May 30, 2012

Received 10 April 2012, accepted subject to revision 18 June 2012, accepted for publication 5 November 2012.

*Corresponding author: Email: Dirk.deGraaf@UGent.be

\section{Summary}

American foulbrood is one of the most devastating diseases of the honey bee. It is caused by the spore-forming, Gram-positive rod-shaped bacterium Paenibacillus larvae. The recent updated genome assembly and annotation for this pathogen now permits in-depth molecular studies. In this paper, selected techniques and protocols for American foulbrood research are provided, mostly in a recipe-like format that permits easy implementation in the laboratory. Topics covered include: working with Paenibacillus larvae, basic microbiological techniques, experimental infection, and "omics" and other sophisticated techniques. Further, this chapter covers other technical information including biosafety measures to guarantee the safe handling of this pathogen.

\section{Métodos para la investigación de la loque americana}

\section{Resumen}

La loque americana es una de las enfermedades más devastadoras de la abeja melífera, causada por el bacilo, formador de esporas Grampositivo Paenibacillus larvae. El reciente ensamblaje y anotación del genoma de este patógeno permite actualmente la realización de profundos estudios moleculares. En este trabajo, se proporcionan técnicas y protocolos seleccionados para la investigación de la loque americana, principalmente bajo la forma de protocolos de trabajo con una estructura similar al de las recetas, para facilitar su implementación en el laboratorio. Los temas desarrollados incluyen: el trabajo con Paenibacillus larvae, técnicas básicas microbiológicas, la infección experimental, y "'ómicas" y otras técnicas sofisticadas. Además, este capítulo abarca otro tipo de información técnica, incluyendo medidas de bioseguridad para garantizar la seguridad en el manejo de este patógeno. 


\section{美洲幼虫腐臭病研究的标准方法}

美洲幼虫腐臭病是最具毁灭性的疾病之一, 由革兰氏阳性杆状菌 Paenibacillus larvae 引起。近年来, 随着基因组学的开展, 该病原体的基因组 组装和注释已成为开展, 深入的分子研究成为可能。本文提供了经选择的美洲幼虫腐臭病研究技术和实验程序, 大多数以“食谱”的格式给出, 很容易在实验室开展操作。覆盖的主题包括：Paenibacillus larvae 的处理技术，基本微生物技术、实验感染技术、“组学”以及其他的一些复杂技 术。此外, 本章还包含了生物安全的评价方法, 以确保安全的开展该病原体的研究

Key words: honey bee, American foulbrood, Paenibacillus larvae, brood, disease, pathogen, technique, BEEBOOK, COLOSS

\section{Table of Contents}

1.

2.

2.1.

2.2 .

2.3.

3.

3.1.

3.2

3.2.1.

3.2.2.

3.3.

3.3.1.

3.3.2.

3.3.2.1

3.3.2.2.

3.3.2.3.

3.4.

3.4.1.

3.4.2.

3.5 .

3.5.1.

3.5.2.

3.5.3.

3.6.

3.6.1.

3.6.2.

3.6.2.1.

3.6.2.2.

3.6.2.3.

4.

4.1.

4.1.1.

4.1.2.

4.2 .

\section{Introduction}

Biosafety measures

Strains

Cultivation

Identification

Bacterial DNA extraction

Polymerase chain reaction

Genotyping

Short-term preservation Paenibacillus larvae disc diffusion method

\section{Preparation of discs}

Preparation of plates

\section{Experimental infection}

Analysis of generated data
Working with Paenibacillus larvae

Sampling for AFB monitoring or diagnosis

Basic microbiological techniques

PCR amplification of repetitive elements

Pulsed-field gel electrophoresis

Preparation of genomic DNA agarose plugs

Restriction enzyme digestion

Gel loading and electrophoresis

In vitro sporulation of Paenibacillus larvae

Sporulation of solid growth medium

Sporulation in liquid growth medium

Long term conservation of vegetative cells

Preservation via ultra-low freezing

Preservation via lyophilization

Measuring susceptibility/resistance to antibiotics of

Determination of minimal inhibitory concentrations (MICs) 12

Determination of antibiotic susceptibility testing by the 12

Determination of resistance/susceptibility

Infection of in vitro reared larvae for the analysis of virulence and pathomechanisms of Paenibacillus larvae

Protocol for exposure bioassays

Experimental infection of a bee colony
Page
No.

3 4.2.1.

3 4.2.2.

34.

3 4.3.1.

3 4.3.2.

35.

Inoculation with known spore concentration solution
Inoculation with diseased brood
Measuring colony resistance to AFB
Surveying inoculated colonies
Colony Resistance

'omics and other sophisticated techniques $\quad 16$

Paenibacillus larvae gene expression $\quad 16$

Reference gene selection 16

Sample collection and storage $\quad 16$

RNA and CDNA preparation 16

Primer design and secondary structures $\quad 16$

qRT-PCR reactions 16

qRT-PCR program 16

qRT-PCR analysis 16

Differential gene expression $\quad 16$

Comparative genome analysis within the species $\quad 16$ Paenibacillus larvae using suppression subtractive hybridization

Conventional proteomics using two-dimensional gel $\quad 18$ electrophoresis

Differential proteomics of Paenibacillus larvae $\quad 19$

Sample preparation 20

Extract proteins 20

Reduce, alkylate and digest proteins to peptides $\quad 20$

Clean up peptides $\quad 20$

Label peptides with stable isotopes $\quad 20$

Clean up peptides 20

Mass spectrometry analysis $\quad 20$

Expression of heterologous proteins in Paenibacillus $\quad 21$ larvae

Transformation of Paenibacillus larvae 21

Detection of GFP-expression $\quad 21$

Fluorescent in situ hybridization for the detection of 22 Paenibacillus larvae

Preparation and embedding of larval tissues 22

Performing fluorescence in situ hybridization 22

Final remarks 22

Acknowledgements 23

References 23 ge

15
15

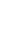
6 .

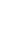

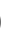

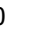
, 1 21

21




\section{Introduction}

American foulbrood (AFB) is a devastating brood disease of the honey bee caused by the spore-forming, Gram-positive rod-shaped bacterium Paenibacillus larvae. AFB is one of the bee diseases listed in the OIE (Office International des Epizooties - the World Organization for Animal Health) Terrestrial Animal Health Code (2011) and member countries and territories are obliged to report its occurrence. In 2006, a draft of the $P$. larvae genome was published at an estimated 5-6x coverage (Qin et al., 2006). Last year, this coverage was further extended and the genome sequence was further annotated with a combination of bioinformatics and proteomics (Chan et al., 2011). These efforts will certainly help to usher in the next level of research for this economically important pathogen, ultimately allowing us to better understand the intimate relationship between the pathogen and its host. More generally, the honey bee / AFB system provides a wealth of opportunities and tools for addressing basic questions regarding microbe-microbe interactions, host immunity, strain virulence, and horizontal transmission, among others.

In the present paper, selected techniques and protocols in American foulbrood research are provided, mostly in a recipe-like format that permits easy implementation in the laboratory. The different topics that are covered include: working with Paenibacillus larvae, basic microbiological techniques, experimental infection and "omics" and other sophisticated techniques. Thus, the chapter covers a broad set of technical information going from biosafety measures to guarantee the safe handling of this pathogen to the expression of heterologous proteins in $P$. larvae. Techniques exclusively related to the diagnosis of AFB are not included as they have been reviewed elsewhere (de Graaf et al., 2006a; OIE, 2008).

\section{Working with Paenibacillus larvae}

\subsection{Biosafety measures}

In some countries, microbial species are categorized in different classes based on biosafety risk. Each biosafety risk class has its own recommendations with respect to facility design, safety equipment, and working practices (de Graaf et al., 2008). This classification mostly takes into account the risk for human health, potential for dispersal of the disease, and the potential economic impact of the disease. However, a generally accepted biosafety risk classification has not been prescribed for $P$. larvae. Consideration of the severity of clinical American foulbrood infections in honey bee colonies, the contagiousness, the longevity of the spores, the legal context of AFB (a notifiable disease), and the economic value of honey bee pollination services, justifies $P$. larvae classification as an organism with 'high biosafety risk for animals'. Table 1 summarizes basic biosafety practices - mainly in accordance with the Belgian model (http://www.biosafety.be/) - that should be considered when manipulating $P$. larvae for research or diagnosis. It should be noted that $P$. larvae has been safely cultured in the laboratory for decades using only standard bacteriological procedures (i.e. aseptic handling techniques and careful decontamination of biological waste), and to date, no known AFB outbreaks due to intentional/accidental laboratory release of this organism have been reported.

\subsection{Strains}

Various $P$. larvae strains can be obtained from bacterial culture collections. However, many of these collection agencies store exactly the same strains but with their own strain designations. This fact is relevant when comparing different $P$. larvae strains for research purposes, or when using strains as positive controls in diagnosis or species identification. Table 2 shows many of the important strains that are available in these culture collections and shows some alternate designations. With regard to obtaining strains, it should be noted that certain countries have import/export and interstate transport shipping regulations regarding the movement and storage of this pathogen (http://www.biosafety.be/RA/Class/ListBact.html).

\subsection{Sampling for AFB monitoring or diagnosis}

Testing for the presence of $P$. larvae may be carried out for different reasons - for example either as part of national monitoring or prevention programmes, or as part of scientific research projects such as epidemiological studies. The proper collection procedure depends on whether the testing is to be carried out following the observation of suspected clinical signs of AFB, or the testing is part of general surveillance to identify a potential sub-clinical presence of $P$. larvae in colonies within a population. These considerations are addressed in the OIE Manual of Diagnostic Tests and Vaccines for Terrestrial Animals vol.1 (OIE, 2008), and we advise readers to consult the AFB chapter in that resource.

\section{Basic microbiological techniques}

\subsection{Cultivation}

As $P$. larvae is a spore-forming bacterium, its isolation from biological samples is typically preceded by a heat treatment step to kill all vegetative microorganisms. This step significantly reduces the risk that $P$. larvae colonies will be masked by competitors. Different genotypes of $P$. larvae show variation in germination ability, and their response to heat treatment is variable (Forsgren et al., 2008). MYPGP agar (Dingman and Stahly, 1983) is routinely used to cultivate $P$. larvae for AFB diagnosis. This medium makes incubation under $\mathrm{CO}_{2}$ unnecessary although the presence of $5 \% \mathrm{CO}_{2}$ significantly increases germination (Nordstrom and Fries, 1995). Contaminants of the genera Bacillus and Brevibacillus, as well as other Paenibacillus species, are 
Table 1. Biosafety rules mainly in accordance to the Belgian model; http://www.biosafety.be/. As this model is very restrictive, we have indicated the rules that are minimally $(\mathbf{M})$ required. The other biosafety rules should be considered optional depending on the demands of the responsible authority.

\begin{tabular}{|c|c|}
\hline Topic & Measurement \\
\hline Facility design & $\begin{array}{l}\text { - The laboratories are physically separated from other work areas in the building. } \\
\text { - The access to the laboratories are locked if the zone or corridor access is not reserved. The doors have automatic closing if they open } \\
\text { directly into a public area. } \\
\text { - (M) The furniture has been designed to allow easy cleaning and disinfection, and easy insect and rodent control. } \\
\text { - (M) There is a sink for washing and decontamination of hands in the laboratory. } \\
\text { - (M) There are coat hooks or a dressing room equipped with protective clothing. Normal clothing and protective clothing should remain } \\
\text { separated. } \\
\text { - (M) The tables are easy to clean, water impermeable and resistant to acids, alkalis, organic solvents, disinfectants and decontamination } \\
\text { agents. }\end{array}$ \\
\hline & $\begin{array}{l}\text { - If the laboratory is equipped with a microbiological safety cabinet (MSC) of class II, it must be localized as such that it does not disturb } \\
\text { the air flow in the room. It should be kept at a sufficient distance from windows, doors, and places with frequent passage, vents for air } \\
\text { intake or outlet. The MSC should be checked and certified upon purchase or relocation, as well as at least once a year afterward. } \\
\text { - There is an autoclave available in the building if the biological waste and/or biological residues shall be inactivated by steam sterilization. } \\
\text { - The centrifuge that will be used is available in the containment zone. If this is not the case, and centrifugation is done outside the } \\
\text { containment zone, the tubes and the rotors should be free of leaks. }\end{array}$ \\
\hline & 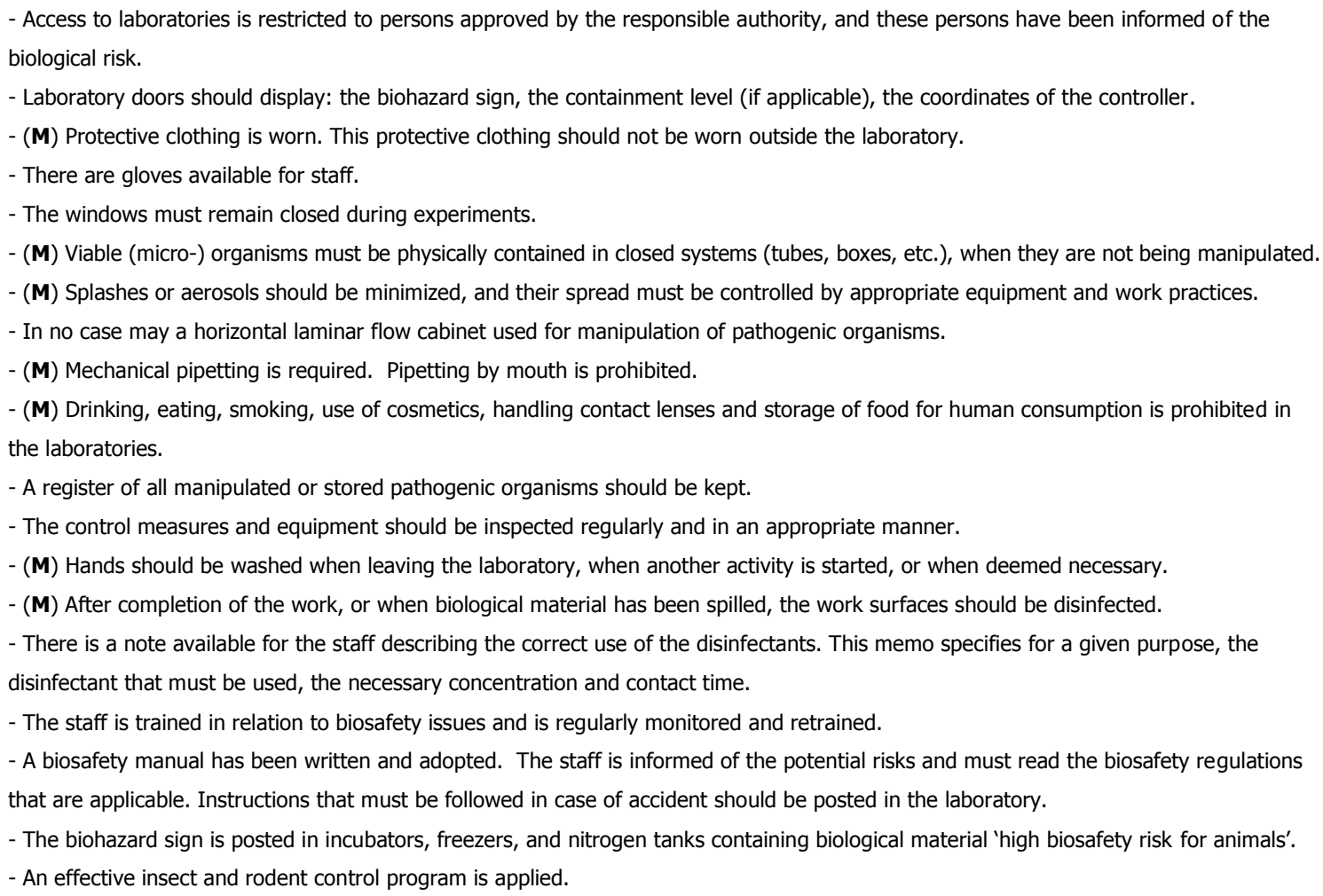 \\
\hline & $\begin{array}{l}\text { - (M) Contaminated biological waste and/or biological residues and contaminated disposable equipment should be inactivated by an } \\
\text { appropriate, validated method before it is discharged--e.g., by autoclaving or by incineration. The incineration is performed by an authorized } \\
\text { company. The waste is collected in secure and hermetically sealable containers. These should be closed for transport. } \\
\text { - (M) Contaminated material (glassware, etc.) is inactivated by an appropriate, validated method before cleaning, reuse and/or destruction. }\end{array}$ \\
\hline
\end{tabular}

inhibited by nalidixic acid (Hornitzky and Clark, 1991) and pipemidic acid (Alippi, 1991; 1995). Apart from brood samples, food stores (honey, pollen and royal jelly), adult workers, and wax debris can also be used to detect the presence of $P$. larvae spores.

The outline of the cultivation procedure starting from brood samples is as follows:

1. Prepare an aqueous solution containing $P$. larvae spores by taking twice samples with a sterile swab from a brood comb (each time multiple brood cells should be sampled), and subsequently suspending them in $5 \mathrm{ml}$ of phosphate buffered saline (PBS).

2. Incubate different aliquots of the spore suspension at 80,85 , 90,95 and $100^{\circ} \mathrm{C}$ for 10 min (Forsgren et al., 2008).

$P$. larvae occurs in two forms: vegetative cells and spores. Only 
Table 2. Strains of Paenibacillus larvae.

\begin{tabular}{|c|c|c|c|c|}
\hline Species & $\begin{array}{l}\text { Old subsp. } \\
\text { classification }\end{array}$ & Strain no. & Other designation & Source \\
\hline \multirow{4}{*}{ Paenibacillus larvae } & \multirow{4}{*}{ larvae } & \multirow{4}{*}{ LMG $9820^{\top}$} & ATCC $9545^{\top}$ & Foulbrood of honey bees \\
\hline & & & DSM $7030^{\top}$ & \\
\hline & & & NRRL B-2605 & E C Holst \#846 \\
\hline & & & LMG $15969^{\top}$ & \\
\hline Paenibacillus larvae & larvae & LMG 14425 & ATCC 25747 & $\begin{array}{l}\text { Ohio, USA, diseased honey bee } \\
\text { larvae }\end{array}$ \\
\hline Paenibacillus larvae & larvae & LMG $15969^{\top}$ & See LMG $9820^{\top}$ & See LMG $9820^{\top}$ \\
\hline Paenibacillus larvae & larvae & LMG 16245 & NRRL B-3650 & $\begin{array}{l}\text { Diseased honey bee larvae } \\
\text { L Bailey, Rothamsted Expt. } \\
\text { Station, Harpenden, UK. strain } \\
\text { Australia ("Victoria") }\end{array}$ \\
\hline Paenibacillus larvae & larvae & LMG 18149 & Hornitzky 89/2302/4 & Victoria, Australia, honey bee \\
\hline \multirow{9}{*}{ Paenibacillus larvae } & \multirow{9}{*}{ pulvifaciens } & \multirow{9}{*}{ LMG $6911^{\top}$} & ATCC $13537^{\top}$ & Dead larvae honey bee \\
\hline & & & DSM $3615^{\top}$ & \\
\hline & & & IFO $15408^{\top}$ & \\
\hline & & & NCIMB $11201^{\top}$ & \\
\hline & & & NRRL B-3688 & \\
\hline & & & NRRL B-3685 & \\
\hline & & & NRRL B-3670 ${ }^{\top}$ & \\
\hline & & & LMG $16248^{\top}$ & \\
\hline & & & LMG $15974^{\top}$ & \\
\hline Paenibacillus larvae & pulvifaciens & LMG 14427 & ATCC 25367 & Unknown \\
\hline Paenibacillus larvae & pulvifaciens & LMG 14428 & ATCC 25368 & Unknown \\
\hline Paenibacillus larvae & pulvifaciens & LMG $15974^{\top}$ & See LMG $6911^{\top}$ & See LMG $6911^{\top}$ \\
\hline Paenibacillus larvae & pulvifaciens & LMG 16247 & NRRL B-3687 & $\begin{array}{l}\text { (1949), honey bee larvae, H } \\
\text { Katznelson \#754 }\end{array}$ \\
\hline Paenibacillus larvae & pulvifaciens & LMG $16248^{\top}$ & See LMG $6911^{\top}$ & See LMG $6911^{\top}$ \\
\hline Paenibacillus larvae & pulvifaciens & LMG 16250 & NRRL B-14154 & Unknown \\
\hline \multirow{4}{*}{ Paenibacillus larvae } & \multirow{4}{*}{ pulvifaciens } & \multirow{4}{*}{ LMG 16251} & CCM 38 & Unknown \\
\hline & & & CCUG 7427 & \\
\hline & & & NCFB 1121 & \\
\hline & & & NRRL NRS-1283 & $\begin{array}{l}\text { Powdery scale, H Katznelson } \\
\text { \#113 }\end{array}$ \\
\hline \multirow{2}{*}{ Paenibacillus larvae } & \multirow{2}{*}{ pulvifaciens } & \multirow{2}{*}{ LMG 16252} & DSM 8443 & Dead honey bee larvae \\
\hline & & & NRRL NRS-1684 & \\
\hline
\end{tabular}

spores are infectious to honey bees. While $P$. larvae sporulates and grows efficiently in the haemolymph of bee larvae, most strains grow poorly in artificial media. Different culture media have been developed for $P$. larvae cultivation. MYPGP agar (Dingman and Stahly, 1983) yielded the highest percentage of spore recovery, while J-agar (Hornitzky and Nicholls, 1993), brain heart infusion agar (BHI) (Gochnauer, 1973), Columbia sheep blood agar (CSA) (Hornitzky and Karlovskis, 1989) proved to be less efficient in this respect (Nordström and Fries, 1995). Other media used for the cultivation of $P$. larvae are
PLA agar (Schuch et al., 2001) and T-HCl-YGP agar (Steinkraus and Morse, 1996). PLA medium shows superior plating efficacy and also the advantage of inhibiting the majority of micro-organisms normally present in the hive and in bee products. T-HCl-YGP agar is the medium of choice for cultivation $P$. larvae starting from honey (Steinkraus and Morse, 1996). When starting from diseased larvae, nalidixic acid is necessary to avoid growth of $P$. alvei. When starting from other sources (e.g. honey), pipemidic acid prevents contamination with other spore-forming bacteria. 
MYPGP agar (per litre):

- $10 \mathrm{~g}$ Mueller-Hinton broth (Oxoid CM0405)

- $15 \mathrm{~g}$ yeast extract

- $3 \mathrm{~g} \mathrm{~K}_{2} \mathrm{HPO}_{4}$

- $1 \mathrm{~g} \mathrm{Na}$-pyruvate

- $20 \mathrm{~g}$ agar

- Autoclave at $121^{\circ} \mathrm{C} / 15 \mathrm{~min}$.

- Add $20 \mathrm{ml} 10 \%$ glucose (autoclaved separately).

BHI agar:

- Suspend $47 \mathrm{~g}$ brain heart infusion agar (Oxoid CM1136) in 1 litre of distilled water.

- Autoclave at $121^{\circ} \mathrm{C}$ for $15 \mathrm{~min}$.

- Add $1 \mathrm{mg}$ thiamine hydrochloride per litre.

\section{CSA-agar:}

- Dissolve $39 \mathrm{~g}$ Columbia blood agar base (Oxoid CM0331) in 1 litre distilled water.

- Autoclave at $121^{\circ} \mathrm{C} / 15 \mathrm{~min}$.

- Supplement with $50 \mathrm{ml}$ sterile defibrinated blood (at $50^{\circ} \mathrm{C}$ ).

T-HCl-YGP (per litre):

- $15 \mathrm{~g}$ yeast extract

- $1 \mathrm{~g}$ pyruvic acid

- $200 \mathrm{ml} 0.1 \mathrm{M}$ Tris-HCl, pH 7.0

- $20 \mathrm{~g}$ agar

- Autoclave at $121^{\circ} \mathrm{C} / 15 \mathrm{~min}$.

- Add $40 \mathrm{ml} 10 \%$ glucose (autoclaved separately).

J agar (per litre):

- $5 \mathrm{~g}$ tryptone

- $3 \mathrm{~g} \mathrm{~K}_{2} \mathrm{HPO}_{4}$

- $15 \mathrm{~g}$ yeast extract

- $20 \mathrm{~g}$ agar

- $\quad$ Adjust pH to 7.3 to 7.5 .

- Autoclave at $121^{\circ} \mathrm{C} / 15 \mathrm{~min}$.

- Add $20 \mathrm{ml} 10 \%$ glucose (autoclaved separately).

PLA medium consists of three different media supplemented with egg yolk. Equal quantities $(100 \mathrm{ml})$ of sterile, molten Bacillus cereus selective agar base (Oxoid CM617), trypticase soy agar (Merck 5458) and supplemented nutrient agar (SNA) are combined and mixed. SNA is composed of (per litre):

- 23 g nutrient agar

- $6 \mathrm{~g}$ yeast extract

- $3 \mathrm{~g}$ meat extract

- $10 \mathrm{~g} \mathrm{NaCl}$

- $2 \mathrm{~g} \mathrm{Na}_{2} \mathrm{HPO}_{4}$

- $\quad$ Adjust pH to $7.4 \pm 0.2$.
All solid media are sterilized at $121^{\circ} \mathrm{C}$ for $15 \mathrm{~min}$. After the three molten media are combined $30 \mathrm{ml}$ of $50 \%$ egg-yolk suspension is added to form the PLA medium.

Cool the media to $50^{\circ} \mathrm{C}$ and add the antibiotics to a final concentration of $20 \mu \mathrm{g} / \mathrm{ml}$ for nalidixic acid and $10 \mu \mathrm{g} / \mathrm{ml}$ for pipemidic acid.

- Nalidixic acid stock solution ( $1 \mathrm{mg} / \mathrm{ml})$ is prepared by dissolving $0.1 \mathrm{~g}$ in $2 \mathrm{ml}$ of $1 \mathrm{M} \mathrm{NaOH}$ and diluting to $100 \mathrm{ml}$ with $0.01 \mathrm{M}$ phosphate buffer ( $\mathrm{pH} 7.2$ ).

- Pipemidic acid stock solution $(2 \mathrm{mg} / \mathrm{ml})$ is prepared by dissolving $0.2 \mathrm{~g}$ in $2 \mathrm{ml}$ of $1 \mathrm{M} \mathrm{NaOH}$ and then diluting to 100 $\mathrm{ml}$ with $0.01 \mathrm{M}$ phosphate buffer ( $\mathrm{pH} 7.2)$.

- Both antibiotic solutions are filter sterilized.

The medium is poured $(20 \mathrm{ml})$ into sterile Petri dishes and plates are dried before use (15 $\mathrm{min}$ ).

Plates inoculated with $150 \mu \mathrm{l}$ heat-shocked spore suspension are incubated at $35^{\circ} \mathrm{C}$ up to 6 days in either aerobic conditions or under an atmosphere of $5-10 \% \mathrm{CO}_{2}$. Vegetative bacteria are grown overnight at $35^{\circ} \mathrm{C}$ without heat-shock treatment.

The outline of the procedure starting from honey samples is as follows:

1. Dilute $20 \mathrm{~g}$ of honey in $20 \mathrm{ml}$ PBS.

2. Shake vigorously.

3. Centrifuge the suspension $40 \mathrm{~min}$ at $6,000 \mathrm{xg}$ to harvest the spores.

4. Resuspend the pellet in $1 \mathrm{ml}$ of PBS.

5. Heat treat and plate this spore containing aqueous solution as described above.

\subsection{Identification}

Often the first step in the identification of $P$. larvae growing on solid media is the verification of its growth rate and colony morphology. Visible colonies may appear on the second day of incubation. However, if no colonies emerge it is advisable to extend the incubation time for a few more days. Two serial subcultures should be grown to insure culture purity. Pure $P$. larvae colonies have a characteristic morphology but this appears to be highly dependent on the medium that was used (see OIE, 2008). Using P. larvae reference strains is highly advisable.

Some non-molecular identification protocols exist and provide a good alternative for diagnostic purposes when sophisticated equipment is lacking (see OIE, 2008). However, for research purposes we recommend a PCR-based identification of $P$. larvae. Several PCR methods have been described (reviewed by de Graaf et al., 2006a), but one in particular based on the 16S rRNA gene (Dobbelaere et al., 2001) has proven its robustness in the past decade. A detailed description is given here below. Primers are listed in Table 3. 
Table 3. Primer sets for identification and genotyping of $P$. larvae by PCR.

\begin{tabular}{|c|c|c|c|}
\hline Name & Sequence & $\begin{array}{l}\text { PCR- } \\
\text { product size }\end{array}$ & Reference \\
\hline $\begin{array}{l}\text { AFB-F } \\
\text { AFB-R }\end{array}$ & $\begin{array}{l}\text { 5'-CTTGTGTTTCTTTCGGGAGACGCCA-3' } \\
\text { 5'-TCTTAGAGTGCCCACCTCTGCG-3' }\end{array}$ & 1106 bp & Dobbelaere et al., 2001 \\
\hline $\begin{array}{l}\text { Primer } 1 \\
\text { Primer } 2\end{array}$ & $\begin{array}{l}\text { 5'-AAGTCGAGCGGACCTTGTGTTTC-3' } \\
\text { 5-'TCTATCTCAAAACCGGTCAGAGG-3' }\end{array}$ & $973 \mathrm{bp}$ & Govan et al., 1999 \\
\hline $\begin{array}{l}\text { ERIC1R } \\
\text { ERIC2 }\end{array}$ & $\begin{array}{l}\text { 5' -ATGTAAGCTCCTGGGGATTCAC-3' } \\
\text { 5' -AAGTAAGTGACTGGGGTGAGCG-3' }\end{array}$ & Several amplicons & Versalovic et al., 1994 \\
\hline BOXA1R & 5'-CTACGGCAAGGCGACGCTGACG-3 & Several amplicons & Versalovic et al., 1994 \\
\hline MBO-REP1 & 5' -CCGCCGTTGCCGCCGTTGCCGCCG-3 & Several amplicons & Versalovic et al., 1994 \\
\hline
\end{tabular}

\subsubsection{Bacterial DNA extraction}

Bacterial DNA extraction can be done using commercialized kits/ matrices (InstaGene matrix, Bio-Rad, Genersch and Otten, 2003; Genome DNA Extraction kit, Sigma, Antúnez et al., 2007). However, heating the bacterial suspension at $95^{\circ} \mathrm{C}$ for $15 \mathrm{~min}$ works also fine for simple species identification.

\subsubsection{Polymerase chain reaction}

PCR reactions (modified from Dobbelaere et al., 2001) are set up as $50 \mu$ mixtures containing:

- 1-5 $\mu$ l template DNA

- 50 pmol forward (AFB-F) and reverse primer (AFB-R); (primers used by Govan et al., 1999 also work well)

- $10 \mathrm{nmol}$ of each dNTP

- 1-2.5 $\mathrm{U}$ of Taq polymerase in the appropriate PCR buffer containing $2 \mathrm{mM} \mathrm{MgCl}_{2}$.

Use the following PCR conditions: a $95^{\circ} \mathrm{C}(1-15 \mathrm{~min})$ step; 30 cycles of $93^{\circ} \mathrm{C}(1 \mathrm{~min}), 55^{\circ} \mathrm{C}(30 \mathrm{sec})$, and $72^{\circ} \mathrm{C}(1 \mathrm{~min})$; and a final cycle of $72^{\circ} \mathrm{C}(5 \mathrm{~min})$.

\subsection{Genotyping}

The availability of standardized techniques that allow the discrimination of different $P$. larvae strains is essential for studying the epidemiology of AFB. This will allow scientists to identify outbreaks of the disease, determine the source of infection, determine the relationship between outbreaks, recognize more virulent strains, and monitor prevention and treatment strategies.

To date different techniques have been used in order to evaluate the diversity of $P$. larvae isolates. Some of them are based on the analysis of phenotypic characteristics, such as study of cell and colony morphology, analysis of whole bacterial proteins by SDS-PAGE or biochemical profile, among others (Hornitzky and Djordevic, 1992; Neuendorf et al., 2004; de Graaf et al., 2006a; Genersch et al., 2006; Antúnez et al., 2007). During the last decade methods based on genetic analysis have gained more attention. Different strategies have been used to evaluate the genetic diversity of $P$. larvae, including restriction endonuclease fragment patterns (Djordjevic et al., 1994; Alippi et al., 2002), pulsed-field gel electrophoresis (Wu et al., 2005; Genersch et al., 2006), amplified fragment length polymorphism (de Graaf et al., 2006b), ribotyping and denaturing gradient gel electrophoresis (Antúnez et al., 2007). Nevertheless, some of these techniques differentiating $P$. larvae genotypes, have not been adopted by the scientific community.

An appropriate genotyping method should be highly discriminatory, but also demonstrate interlaboratory and intralaboratory reproducibility. It should be easy to use and interpret (Genersch and Otten, 2003). For these reasons, the most utilized method is rep-PCR, or PCR amplification of repetitive elements (Versalovic et al., 1994), although presently its reproducibility in other labs has not been proven. There are three sets of repetitive elements randomly dispersed in the genome of bacteria, enterobacterial repetitive intergenic consensus (ERIC) sequences, repetitive extragenic palindromic (REP) elements, and $\mathrm{BOX}$ elements (which includes boxA, boxB, and boxC). Primers to amplify those elements have been reported and proved to be useful for subtyping of Gram-positive and Gram-negative bacteria (Versalovic et al., 1994; Olive and Bean, 1999).

rep-PCR has been widely used for the study of $P$. larvae (Alippi and Aguilar, 1998a, 1998b; Genersch and Otten, 2003; Alippi et al., 2004; Antúnez et al., 2007; Peters et al., 2006; Loncaric et al., 2009). The most useful pair of primers are ERIC1R-ERIC2, which allowed the differentiation of four different genotypes (ERIC I, II, III and IV) (Genersch et al., 2006). Genotypes ERIC I and II corresponds to the former subspecies $P$. I. larvae while genotypes ERIC III and IV corresponds to the former subspecies $P$. I. pulvifaciens (Genersch, 2010).

$P$. larvae genotype ERIC I is the most frequent genotype and is present in Europe and in America, genotype ERIC II seems to be restricted to Europe and genotypes ERIC III and IV have not been identified in field for decades, but exist as few isolates in culture collections (Genersch, 2010). In order to enhance the discrimination of strains, the analysis using ERIC primers can be complemented with the use of other primers. The use of BOXA1R primer allowed the 
discrimination of four banding patterns in America, all of them belonging to genotype ERIC I (Alippi et al., 2004; Antúnez et al., 2007) and three in Europe (Genersch and Otten, 2003; Peters et al., 2006; Loncaric et al., 2009). Primers BOX B1 and BOX C1 did not amplify P. larvae DNA (Genersch and Otten, 2003). When REP primers were used, four banding patterns were found in America and Europe although results could not be compared since different pairs of primers (REP1R-I and REP2-I and MBO REP1 primers) were used (Alippi et al., 2004; Kilwinski et al., 2004; Loncaric et al., 2009). Protocols for subtyping of $P$. larvae are provided below.

Restriction fragment length polymorphic (RFLP) analysis of bacterial genomes, as visualized via pulsed-field gel electrophoresis (PFGE), is also a very effective procedure for bacterial genotyping (PFGE-typing). PFGE-typing of 44 P. larvae isolates, obtained from honey bee larval smears and honey samples collected in Australia and from Argentinean honey, has demonstrated resolution of this bacterium into 12 distinct genotypes when using restriction endonuclease $X b a I$ (Wu et al., 2005). Outlined below is a PFGE-typing procedure for $P$. larvae. This procedure is presented as a three-part operation of genomic DNA preparation, restriction digestion of DNA, and then electrophoresis of the digested DNA. Performance of PFGEtyping is labour intensive. Also, many factors can contribute to an unsuccessful electrophoresis run. Therefore, troubleshooting PFGE and helpful hints for performing this technique can be found in the protocols section of the Bio-Rad website (http://www.bio-rad.com/ evportal/en/US/LSR/Solutions/LUSORPDFX/Pulsed-Field-GelElectrophoresis).

\subsubsection{PCR amplification of repetitive elements}

Polymerase chain reaction (according to Genersch and Otten, 2003):

1. Carry out PCR reactions in a final volume of $25 \mu \mathrm{l}$ consisting of $1 \times$ reaction buffer and a final concentration of $2.5 \mathrm{mM} \mathrm{MgCl}_{2}$, $250 \mu \mathrm{M}$ of each dNTP, $10 \mu \mathrm{M}$ of primer, and $0.3 \mu \mathrm{g}$ of Hot start Taq polymerase. Five to ten $\mu \mathrm{l}$ of template DNA is added to the reaction.

2. The cycling conditions are: an initial activation step at $95^{\circ} \mathrm{C}$ for $15 \mathrm{~min}, 35 \mathrm{cycles}$ at $94^{\circ} \mathrm{C}$ for $1 \mathrm{~min}, 53^{\circ} \mathrm{C}$ for $1 \mathrm{~min}$, and at $72^{\circ} \mathrm{C}$ for $2.5 \mathrm{~min}$, and a final elongation step at $72^{\circ} \mathrm{C}$ for 10 $\min$.

3. Analyse five $\mu \mathrm{l}$ of the PCR reaction by electrophoresis on $0.8 \%$ agarose gel in TAE or TBE buffer.

4. Stain the amplified bands by incubation of the agarose gel in ethidium bromide $(0.5 \mu \mathrm{g} / \mathrm{ml}$ in water) for $30 \mathrm{~min}$.

5. Visualize under UV light and photograph using a digital camera.

6. Compare obtained fingerprints visually or using specific analysis programs.

Independent PCR reactions should be performed using primers

ERIC1R/ERIC2, BOXA1R and MBO-REP1 (Table 3).
Modifications of the present protocol, such as those reported by Alippi et al. (2004) or Antúnez et al. (2007) also resulted useful, allowing the differentiation of $P$. larvae genotypes.

Interpretation of the results:

- ERIC1R-ERIC2 primers: four different genotypes (ERIC I, II, III and IV) can be distinguished (Genersch et al., 2006).

- BOXA1R primers: three different patterns can be found in Europe (A, a and $\cdot$ ) (Genersch and Otten, 2003) while four patterns can be found in America (A, B, C and D) (Alippi et al., 2004).

- MBO REP1 primers: four band patterns can be found in Europe (B, b, $\beta, 5)$ (Peters et al., 2006).

\subsubsection{Pulsed-field gel electrophoresis}

\subsubsection{Preparation of genomic DNA agarose plugs}

1. Culture an isolate of $P$. larvae on an MYPGP agar plate for $48 \mathrm{~h}$ at $37^{\circ} \mathrm{C}$.

2. Suspend a loopful of bacteria (2-3 colonies from an isolated area on the plate) into $500 \mu$ MYPGP broth and centrifuge for $1 \mathrm{~min}$ at RT.

3. Remove the broth, suspend the pellet with $1 \mathrm{ml}$ washing buffer (see recipe below), and centrifuge for $1 \mathrm{~min}$ at RT.

4. Remove the washing buffer.

5. Completely suspend the bacterial cell pellet in $0.30 \mathrm{ml}$ washing buffer $+0.05 \mathrm{ml}$ Proteinase $\mathrm{K}(0.5 \mathrm{mg} / \mathrm{ml})$.

6. Warm the suspension to $50^{\circ} \mathrm{C}$.

7. Mix the suspension with an equal volume of melted $2 \%$ SeaKem Gold agarose (prepared in washing buffer; Cambrex Bio Science Rockland, Inc., ME) at $50^{\circ} \mathrm{C}$.

8. Quickly pipette into two wells of a plug mold (Bio-Rad Laboratories, Inc.) warmed to $37^{\circ} \mathrm{C}$.

9. Solidify the plugs at $4^{\circ} \mathrm{C}$ for $30 \mathrm{~min}$

10. Remove the two plugs from the mold.

11. Add plugs to $5 \mathrm{ml}$ preheated Proteinase $\mathrm{K}$ Solution in a $50 \mathrm{ml}$ plastic culture tube.

12. Incubate overnight at $50^{\circ} \mathrm{C}$ with gentle agitation (shaker water bath).

13. Preheat $10 \mathrm{ml} \mathrm{H}_{2} \mathrm{O}$ and $40 \mathrm{ml}$ TE80 buffer (see recipe below) to $50^{\circ} \mathrm{C}$.

14. Wash plugs (use a sterile BioRad green screened caps; part \#170-3711) with $10 \mathrm{ml} 50^{\circ} \mathrm{C} \mathrm{H}_{2} \mathrm{O}$ (add, swirl, and drain).

15. Wash plugs with $10 \mathrm{ml} 50^{\circ} \mathrm{C}$ TE 80 buffer $4 \mathrm{X}$ (15 min for each wash with gentle shaking).

16. Add $5 \mathrm{ml} \mathrm{RT} \mathrm{TE80} \mathrm{buffer} \mathrm{to} \mathrm{the} \mathrm{plugs} \mathrm{in} \mathrm{the} 50 \mathrm{ml}$ culture tube and store at $4^{\circ} \mathrm{C}$. Plugs are good for approximately 2 months in TE80 buffer at $4^{\circ} \mathrm{C}$.

Wash Buffer (100 ml):

- $200 \mathrm{mM} \mathrm{NaCl}(4.0 \mathrm{ml}$ of $5 \mathrm{M}$ stock)

- $10 \mathrm{mM}$ Tris-HCl (pH 7.5) (1.0 ml of $1 \mathrm{M}$ stock)

- $100 \mathrm{mM}$ EDTA (20.0 ml of $0.5 \mathrm{M}$ stock) 
Proteinase K Solution $(100 \mathrm{ml})$ :

- $50 \mathrm{mM}$ EDTA ( $10.0 \mathrm{ml}$ of $0.5 \mathrm{M}$ stock)

- $1.0 \mathrm{~g} \mathrm{~N}$-lauroylsarcosine

- $50 \mathrm{mg}$ Proteinase $\mathrm{K}$ (final $0.5 \mathrm{mg} / \mathrm{ml}$ )

- $50 \mathrm{mg}$ Lysozyme (final $0.5 \mathrm{mg} / \mathrm{ml}$ )

TE80 Buffer (100ml):

- $10 \mathrm{mM}$ Tris- $\mathrm{HCl}$ (pH 8.0) (1.0 ml of 1 M stock)

- $1 \mathrm{mM}$ EDTA (0.2 ml of $500 \mathrm{mM}$ stock)

\subsubsection{Restriction enzyme digestion}

1. Aseptically remove a plug from the TE80 buffer and place onto the inner surface of a sterile petri dish.

2. Using a plastic ruler under the petri dish, cut two $2 \mathrm{~mm}$ slices from the plug with a sterile razor blade.

3. Place the two plug slices into $1 \mathrm{ml}$ TE80 buffer in a $1.5 \mathrm{ml}$ microcentrifuge tube.

4. Wash the slices $2 \mathrm{X}$ with $1 \mathrm{ml}$ TE80 buffer (30 min for each wash with gentle agitation).

5. Quickly rinse the slices with $500 \mu l$ restriction digestion buffer (without restriction enzyme).

6. Add $100 \mu \mathrm{l}$ of $X$ baI Digestion Mixture (see recipe below) and incubate $3 \mathrm{~h}$ at $37^{\circ} \mathrm{C}$ with gentle agitation.

7. Remove digestion mixture solution.

8. Rinse slices $2 X$ with $1 \mathrm{ml} 0.5 X$ TBE Buffer (see recipe below).

9. Suspend the plug slices in $1 \mathrm{ml} \mathrm{0.5X}$ TBE Buffer.

10. Store overnight at $4^{\circ} \mathrm{C}$.

Xbal Digestion Mixture (10 samples):

- 10X New England BioLabs Buffer $4(100 \mu \mathrm{l})$

- 100X BSA $(10 \mu \mathrm{l})$

- XbaI enzyme (20 $\mu \mathrm{l})$ New England BioLabs $(20,000 \mathrm{U} / \mathrm{ml})$

- $\mathrm{H}_{2} \mathrm{O}(870 \mu \mathrm{l})$

$5 X$ TBE Buffer (500 ml):

- Tris Base $(54 \mathrm{~g})$

- Boric Acid (27.5 g)

- 0.5 M EDTA (pH 8.0) (20 ml)

- $\mathrm{H}_{2} \mathrm{O}$ to $500 \mathrm{ml}$ volume

\subsubsection{Gel loading and electrophoresis}

1. Make 2.3 litres of $0.5 X$ TBE buffer $(230 \mathrm{ml} 5 X$ TBE $+2070 \mathrm{ml}$ $\mathrm{H}_{2} \mathrm{O}$ ).

2. Add $1.0 \mathrm{~g}$ Seakem Gold agarose to $100 \mathrm{ml} 0.5 \mathrm{X}$ TBE Buffer.

3. Carefully melt agarose in microwave oven. Save $5 \mathrm{ml}$ (at $55^{\circ} \mathrm{C}$ ) to seal the wells.

4. Assemble the gel forming tray, assure that the tray is level with the well comb in place, and pour melted agarose into forming tray (cool melted agarose to $55-60^{\circ} \mathrm{C}$ before pouring).
5. Allow gel to solidify for a minimum of $30 \mathrm{~min}$.

6. Add remaining 2.2 litres of $0.5 X$ TBE buffer to the CHEF electrophoresis box.

7. Chill the buffer to $14^{\circ} \mathrm{C}$ by circulation through the chiller-pump unit.

8. Adjust flow rate of buffer through the chiller-pump unit to between 0.75 and $1.0 \mathrm{l} / \mathrm{min}$.

9. Once gel has solidified and the comb is removed, remove a digested plug slice from the microcentrifuge tube.

10. Place the slice onto inner surface of sterile Petri dish.

11. Carefully slide the plug slice onto the side of a sterile razor blade using a sterile microspatula.

12. Holding the razor blade (with the plug slice sticking to the side) at the edge of a well, carefully use the microspatula to slide the plug slice into the well. Use care not to introduce air bubbles in the well.

13. Wash and flame sterilize the razor blade and microspatula for continued loading of wells with other prepared DNA plug slices.

14. Add low range molecular size standards (4.9-120 kb) (Bio-Rad) to outer wells.

15. Seal the wells with the saved SeaKem Gold agarose. Use care not to introduce any air bubbles during sealing and fill any wells that do not contain slices.

16. Place the gel into the circulating pre-cooled buffer within the CHEF electrophoresis box

17. Allow the gel to cool for 15 min prior to beginning electrophoresis.

18. Perform electrophoresis in the Bio-Rad CHEF DR III system using the following electrophoresis run parameters:

- Switch angle: $120^{\circ}$

- Switch time: 1-6 sec

- Voltage: $6 \mathrm{~V} / \mathrm{cm}$

- Temperature: $14^{\circ} \mathrm{C}$

- Run time: 16 hours

19. Following electrophoresis, remove and stain the gel in the dark with Sybr Green (Molecular Probes, Inc., Eugene, OR) (30 $\mu$ l of 10,000X concentrate diluted into $300 \mathrm{ml} \mathrm{TE} \mathrm{pH} \mathrm{7.5)}$ at RT for $45 \mathrm{~min}$.

20. Photodocument the gel via UV transillumination/epi-illumination (254 nm).

\subsection{In vitro sporulation of Paenibacillus larvae}

Paenibacillus larvae and Paenibacillus popilliae, "catalase-minus" paenibacilli as defined by the loop test (i.e. scraping growth from a slant or plate with an inoculating loop, placing into $3 \% \mathrm{H}_{2} \mathrm{O}_{2}$, and examining for bubble formation), have the characteristic of sporulating efficiently in their insect hosts, but usually exhibit very poor sporulation when general in vitro growth conditions are used. 
For $P$. larvae, suppression of in vitro sporulation has been postulated to result from oxygen toxicity (Dingman and Stahly, 1984). Growth of strain NRRL B-3650 under limiting $\mathrm{O}_{2}$ improves sporulation in liquid culture. Also, nutrient availability at time of sporulation has been shown to influence spore production (Dingman and Stahly, 1983).

Procedures promoting effective sporulation of $P$. larvae on solid and in liquid, growth media have been developed (Dingman, 1983). By limiting colony number, many strains have been observed to sporulate well on MYPGP agar plates (see section 3.1. for recipe). However, Mueller-Hinton broth - one of its ingredients - was inhibitory to sporulation of strain NRRL B-3650 in liquid culture, rendering use of this growth medium in liquid form ineffective for sporulation. Development of a liquid growth medium (TMYGP; 1.5\% Difco yeast extract; $0.4 \%$ glucose; $0.1 \%$ sodium pyruvate; $0.03 \mathrm{M}$ Tris -maleate, $\mathrm{pH} 7.0$; in distilled water) and conditions that aided sporulation of $P$. larvae NRRL B-3650 has been reported (Dingman and Stahly, 1983). Unfortunately, other strains of this bacterium sporulated poorly, if at all, in this medium. However, Genersch et al. (2005) reported using the liquid part of Columbia sheep-blood agar slants for production of endospores from different $P$. larvae strains. Following are protocols using solid and liquid media growth conditions for in vitro sporulation of $P$. larvae.

\subsubsection{Sporulation on solid growth medium}

1. Create a 2-fold dilution series of the $P$. larvae bacterial culture being studied using MYPGP broth and spread each dilution onto several MYPGP agar plates (see section 3.1. for recipe).

2. Incubate plates at $37^{\circ} \mathrm{C}$ for $6-7$ days and select plates exhibiting 50 to 5,000 colonies per plate. Note: When high numbers of colonies are present on a plate, sporulation efficiency can decline. Also, maximum sporulation obtained in relation to the plate colony number will vary between bacterial strains.

3. During the 6-7 days of incubation, microscopically monitor cellular growth and sporulation via single colony analysis.

4. After incubation, remove spores from the surface of the agar medium by washing three times ( $5 \mathrm{ml}$ sterile $\mathrm{H}_{2} \mathrm{O}$ per wash).

5. Combine the three washes. Once $\mathrm{H}_{2} \mathrm{O}$ is added to a plate, use gentle rubbing of the agar surface with the sterile glass pipette to loosen spores from the surface.

6. To produce a spore stock following removal of spores from a plate surface, concentrate the spore suspension via centrifugation $\left(12,000 \times \mathrm{g}, 15 \mathrm{~min}, 4^{\circ} \mathrm{C}\right)$.

7. Discard the supernatant.

8. Suspend the resulting spore pellet in $30 \mathrm{ml}$ cold sterile $\mathrm{H}_{2} \mathrm{O}$.

9. Perform alternate centrifugation and pellet suspension four times.

10. Suspend the spore pellet in a final volume of $5 \mathrm{ml}$ cold sterile $\mathrm{H}_{2} \mathrm{O}$.
11. Store at $4^{\circ} \mathrm{C}$. Note: Spores must be removed from the solid growth medium for preservation. When left on the agar plates for extended time, heat-resistant counts decline rapidly (Dingman, 1983). Also, long-term survival of washed spores that have been desiccated is not known.

12. Obtain spore concentration by heating a portion of the spore stock at $65^{\circ} \mathrm{C}$ for $15 \mathrm{~min}$.

13. Perform serial-dilution plating onto MYPGP or T-HCl-YGP (Steinkraus and Morse, 1996) agar plates.

14. Incubate inoculated plates $6-7$ days at $37^{\circ} \mathrm{C}$ to determine colony counts (i.e., spore counts). Alternatively, determine spore number by direct microscopic counting. Note: The latter will give an overestimation. Heat resistant spore counts are usually about $6 \%$ of direct microscopic spore counts (Dingman and Stahly, 1983).

\subsubsection{Sporulation in liquid growth medium}

1. Inoculate TMYGP broth $(6 \mathrm{ml}$ in a $20 \times 150 \mathrm{~mm}$ loosely capped screw-cap glass culture tube, see section 3.1. for recipe) with $P$. larvae NRRL B-3650. Note: Other bacterial strains must be tested separately because they may sporulate poorly in this medium and under these growth conditions.

2. Incubate the culture at $37^{\circ} \mathrm{C}$ in a rotary incubator shaker adjusted to $195 \mathrm{rpm}$. The culture tube is held at a $45^{\circ}$ angle in a wire test tube rack during incubation and aeration.

3. Incubate for 3 to 4 days while microscopically monitoring cellular growth and sporulation. Other strains of $P$. larvae may require a longer incubation time for sporulation to occur. Alternatively, see Genersch et al. (2005) for sporulation of $P$. larvae in the liquid part of Columbia sheep-blood agar slants.

4. Collect and concentrate spores via centrifugation.

5. Wash the spores four times with $30 \mathrm{ml}$ cold sterile $\mathrm{H}_{2} \mathrm{O}$ (as described in section 3.4.1.).

6. Suspend the washed spores in a final volume of $5 \mathrm{ml}$ cold $\mathrm{H}_{2} \mathrm{O}$.

7. Store at $4^{\circ} \mathrm{C}$.

8. Obtain spore counts (i.e. heat resistant counts) by serialdilution plating of the spore suspension onto MYPGP plates following heating of the suspension at $65^{\circ} \mathrm{C}$ for $15 \mathrm{~min}$ or determine counts by direct microscopic counting.

Note: Heat resistant spore counts are usually about $6 \%$ of direct microscopic spore counts (Dingman and Stahly, 1983).

\subsection{Long term conservation of vegetative cells}

Experimental work using $P$. larvae requires a readily available source of this bacterium in culture. However, $P$. larvae quickly dies in culture and some means of preserving an isolate must be used. Although short-term preservation works (see section 3.5.1.), long-term conservation is required to maintain the genetic integrity of the original isolate. 
Production of frozen endospore stock suspensions is a very good procedure for long-term preservation. However, some isolates may not sporulate well in vitro and the slow rate of spore germination can hamper the start of experiments. Methods employing ultra-low freezing and lyophilization of vegetative cells (see sections 3.5.2. and 3.5.3. below) are suitable for long-term storage of this microbe.

Use of ultra-low freezing of $P$. larvae in glycerol has been routinely used and cultures exceeding five years of storage at $-80^{\circ} \mathrm{C}$ remain viable (Douglas W Dingman; personal observations). No known research regarding preservation of $P$. larvae by lyophilization has been published. However, Haynes et al. (1961) developed a method to preserve $P$. popilliae by lyophilization and Gordon et al. (1973) imply that this method can be used for $P$. larvae. The protocol long used to preserve $P$. larvae strains at the National Center for Agricultural Utilization Research (USDA-ARS Culture Collection; NRRL) is similar to that described by Haynes et al. (1961) for P. popilliae.

\subsubsection{Short-term preservation}

1. Weekly transfer of an isolate onto fresh growth medium.

2. Incubate for two days at $37^{\circ} \mathrm{C}$.

3. Store at $4^{\circ} \mathrm{C}$.

\subsubsection{Preservation via ultra-low freezing}

1. Inoculate MYPGP broth (see section 3.1. for recipe) using a fresh culture of $P$. larvae.

2. Grow overnight at $37^{\circ} \mathrm{C}$ with moderate aeration.

3. Growth in the morning should show light to moderate turbidity. Note: Turbidity should not reach the point where the culture has become opaque. A light turbidity will place the culture in early to mid-exponential growth. Also, growth can be washed from the surface of a solid medium using fresh liquid medium.

4. Examine the culture microscopically to gauge contamination while chilling the culture on ice (optional).

5. Add an appropriate volume of a sterile solution of $100 \%$ glycerol to the culture to produce a bacterial suspension containing $20 \%$ glycerol (i.e. $0.25 \mathrm{ml}$ of glycerol per $1.0 \mathrm{ml}$ of culture).

6. Aliquot $0.5 \mathrm{ml}$ of the bacterial / glycerol suspension into cryovials. Snap-top microcentrifuge tubes also work, but may result in faster loss of viability during storage.

7. Label and date the vials.

8. (Optional) Quickly freeze the aliquots in an ethanol/dry ice bath.

9. Place the bacterial suspensions in a pre-chilled storage box and store at $-80^{\circ} \mathrm{C}$.

\subsubsection{Preservation via lyophilization}

(J. Swezey, USDA-ARS Culture Collection (NRRL), Peoria , IL; personal communication)
To prepare lyophilization vials:

1. Cut Pyrex glass tubing ( $6 \mathrm{~mm}$ diameter glass with $1 \mathrm{~mm}$ wall thickness) $15 \mathrm{~cm}$ long and seal one end by melting.

2. Plug the open ends of the vials with cotton.

3. Autoclave. Note: Ampules using rubber septa and aluminium sealing rings may be used as an alternative to the above three steps. However, use of these ampules increase costs and the vacuum may be lost over time.

4. After 2-3 days incubation of the bacterium from an agar slant/ plate, wash with sterile bovine serum (e.g. Colorado Serum Co., Denver, CO).

5. Place $0.1 \mathrm{ml}$ aliquots of the cell/serum suspension into the sterilized vials, label, date.

6. Attach the vials to a lyophilizer apparatus.

7. Lower the vials into a solution of $50 \%$ ethylene glycol and $50 \%$ water (chilled to $-50^{\circ} \mathrm{C}$ with dry ice) to freeze the cell suspensions.

8. Turn on the lyophilizer vacuum pump.

9. Evacuate for 3 hours while letting the temperature of the glycol/water bath gradually warm to $-4^{\circ} \mathrm{C}$.

10. Lift the vials from the glycol/water bath.

11. Allow the outer surfaces to dry for 1 hour at RT.

12. Carefully cut the vials from the lyophilizer apparatus using a dual tip burner, running on natural gas and oxygen, to melt the upper portion of the glass vial while sealing the contents under vacuum.

13. Store sealed vials refrigerated in the dark.

\subsection{Measuring susceptibility/resistance to antibiotics of Paenibacillus larvae}

In some countries, the antibiotic oxytetracycline (OTC) has been used by beekeepers for decades to prevent and control AFB in honey bee colonies as an alternative to the burning of infected beehives in areas where disease incidence is high. However, the intensive use of tetracyclines in professional beekeeping resulted in tetracyclineresistant $\left(T^{R}\right)$ and oxytetracycline-resistant $\left(O T C^{R}\right) P$. larvae isolates. There is now general concern about widespread resistance involving horizontal-transfer via non-genomic (i.e. plasmid or conjugal transposon) routes and also induced resistance by the presence of sub-inhibitory concentrations of tetracycline (Alippi et al., 2007). $P$. larvae highly resistant phenotypes have been correlated with the presence of natural plasmids carrying different Tc resistance determinants, including tetK and tetL genes (Murray and Aronstein, 2006; Alippi et al., 2007; Murray et al., 2007).

Most Paenibacillus species, including $P$. larvae, are highly susceptible to tetracyclines; it has been reported that the growth of $P$. larvae strains is inhibited at concentrations as low as $0.012 \mu \mathrm{g}$ of oxytetracycline per $\mathrm{ml}$ of culture medium. Alternatively, when a disc containing $5 \mu \mathrm{g}$ of oxytetracycline is placed on an agar plate previously spread with a bacterial suspension, the clear zones formed by the 
sensitive strains usually average $50 \mathrm{~mm}$ in diameter including the disc (Shimanuki and Knox, 2000). Any reduction of the inhibition zone or an increase in the minimal inhibitory concentration (MIC) required to prevent the growth of $P$. larvae would be evidence of the development of resistant strains.

\subsubsection{Determination of minimal inhibitory concentrations (MICs)} Microorganisms can be tested for their ability to produce visible growth on a series of agar plates (agar dilution), in tubes with broth (broth dilution), or in microplate wells of broth (broth microdilution) containing dilutions of an antimicrobial agent. Additionally, gradient MIC tests are also commercially available. MIC is defined as the lowest antibiotic concentration that prevents visible growth of bacteria. MIC methods are widely used in the comparative testing of new agents, or when a more accurate result is required for clinical management. As there are no CLSI (formerly NCCLS) (www.clsi.org) nor EUCAST (www.eucast.org) recommendations for the determination of MICs of $P$. larvae, MIC values of tetracycline and other antibiotics can be determined by the agar dilution method using MYPGP as basal medium (see section 3.1. for recipe) as described as follows:

1. Obtain antimicrobial powders directly from the manufacturer or from commercial sources. The agent must be supplied with a stated potency ( $\mathrm{mg}$ or International Units per g powder, or as percentage potency)

2. Store powders in sealed containers in the dark at $4^{\circ} \mathrm{C}$ with a desiccant unless otherwise recommended by the manufacturer.

3. Prepare antibiotic stock solutions by using the following formula:

$$
=\frac{\text { Weight of powder }(\mathrm{mg})}{\text { Volume of solvent }(\mathrm{ml}) \times \text { Concentration }(\mu \mathrm{g} / \mathrm{ml})}
$$

4. It is recommended that concentrations of stock solutions should be $1,000 \mu \mathrm{g} / \mathrm{ml}$ or greater. In the case of tetracyclines, the tested concentrations can be achieved by using two stock solutions of $5,000 \mu \mathrm{g} / \mathrm{ml}$ and $1,000 \mu \mathrm{g}$ tetracycline $/ \mathrm{ml}$ in ethanol, stored at $-20^{\circ} \mathrm{C}$ in darkness until used.

5. Prepare MYPGP agar flasks and maintain them at $45^{\circ} \mathrm{C}$ until the antibiotic solutions are incorporated.

6. Pour $25 \mathrm{ml}$ of culture medium onto each Petri dish of $90 \mathrm{~mm}$ in diameter to give a level depth of $4 \mathrm{~mm} \pm 0.5 \mathrm{~mm}$. If using $150 \mathrm{~mm}$ diameter Petri dishes, $70 \mathrm{ml}$ of culture medium should be dispensed.

7. Prepare plates with increasing concentrations of tetracycline i.e.: $0.03,0.06,0.125,0.25,0.5,1,2,4,8,16,32,64$, and $128 \mu \mathrm{g} / \mathrm{ml}$. For the controls, MYPGP agar without antibiotic is used.

8. Allow the plates to set at RT before moving them.
9. Dry the plates in a sterile laminar flow cabinet so that no drops of moisture remain on the surface of the agar; do not over-dry plates.

10. Incubate each $P$. larvae strain to be tested on MYPGP agar for $48 \mathrm{~h}$ at $36^{\circ} \mathrm{C}$ to obtain mainly vegetative cells.

11. Adjust the bacterial suspension until the $\mathrm{OD}_{620}$ (density of a culture determined spectrophotometrically by measuring its optical density at $620 \mathrm{~nm}$ ) is about 0.4 .

12. Each bacterial suspension of each strain must be inoculated onto the surface of the culture medium by adding drops of $5 \mu \mathrm{l}$ each by means of an automatic micropipette (usually 15-20 drops per plate).

It is possible to test different strains on the same plate. This procedure must be repeated at least twice for each strain and tetracycline concentration, and control plates without antibiotic must be used. It is strongly recommended to include control strains with known MICs in each batch.

13. Place the plates open into a sterile laminar flow cabinet until the drops are absorbed.

14. Incubate the plates in inverted position at $36^{\circ} \mathrm{C} \pm 1$ for $48 \mathrm{~h}$.

15. After incubation, ensure that each tested strain has grown on the antibiotic-free plate control.

16. Read the MIC endpoint for each strain as the lowest concentration of antibiotic at which there is no visible growth. The growth of one or two colonies or a fine film of growth should be disregarded.

Interpretation: for tetracyclines, $P$. larvae isolates should be considered as "susceptible" when there MICs are $<4 \mu \mathrm{g} / \mathrm{ml}$, "intermediate" for MICs between 4-8 $\mu \mathrm{g} / \mathrm{ml}$ and "resistant"' for MICs $\geq 16$. Examples of acceptable MIC values for control strains are: Pseudomonas aeruginosa (ATCC 27853): between $16-32 \mu \mathrm{g} / \mathrm{ml}$ (resistant); Escherichia coli (ATCC 25922): between 0.5-2 $\mu \mathrm{g} / \mathrm{ml}$ (susceptible); Staphylococcus aureus (ATCC 29213): between 0.12-1 $\mu \mathrm{g} / \mathrm{ml}$ (susceptible) and Enterococcus faecalis (ATCC 29212): between $16-32 \mu \mathrm{g} / \mathrm{ml}$ (resistant).

When examining a population of bacteria, it is suggested to calculate their values of $\mathrm{MIC}_{50}$ and $\mathrm{MIC}_{90}$ (minimum concentration necessary to inhibit the growth of 50 and $90 \%$ of microorganisms tested respectively).

\subsubsection{Determination of antibiotic susceptibility testing by the disc diffusion method}

The disc diffusion method of antibiotic susceptibility testing is the most practical method for determining antibiotic susceptibility/resistance of microorganisms to different antimicrobial agents. The accuracy and reproducibility of this test are dependent on maintaining standard procedures. As there are no CLSI (formerly NCCLS) (www.clsi.org) nor EUCAST (www.eucast.org) recommendations for the determination of susceptibility/resistance of $P$. larvae by the disc diffusion method, a method developed for this species is described below. 
For determining tetracycline resistance, the agar diffusion procedure can be employed, using MYPGP agar (see section 3.1. for recipe) and $5 \mu \mathrm{g}$ tetracycline discs $\left(\mathrm{Oxoid}^{\circledR}\right.$ or $\mathrm{BBL}^{\circledR}$ ). The discs can also be prepared in the laboratory by using $S \& S^{\circledR}$ or similar sterile discs $(6 \mathrm{~mm}$ in diameter) impregnated with $5 \mu \mathrm{g}$ tetracycline per disc.

\subsubsection{Preparation of discs}

1. Prepare a stock ethanol solution containing $500 \mu \mathrm{g} / \mathrm{ml}$ of tetracycline as explained in section 3.6.1.

2. Pipette $10 \mu \mathrm{l}$ of the stock solution onto each sterile disc.

3. Dry the discs in a sterile laminar flow cabinet.

4. Store in sterile containers at $-20^{\circ} \mathrm{C}$ in darkness until used. Note: Other tetracyclines (e.g., oxytetracycline) can be tested in the same way. Discs containing antibiotics other than tetracyclines should be prepared at the concentrations suggested by CLSI or EUCAST.

\subsubsection{Preparation of plates}

1. Dispense MYPGP-agar cooled below $50^{\circ} \mathrm{C}$ into sterile Petri dishes to give a level depth of $4 \mathrm{~mm} \pm 0.5 \mathrm{~mm}$ ( $25 \mathrm{ml}$ in $90 \mathrm{~mm}$ diameter Petri dish, $70 \mathrm{ml}$ in $150 \mathrm{~mm}$ diameter Petri dish).

2. Allow the agar to set before moving the plates.

3. Prepared plates can be stored at $4-8^{\circ} \mathrm{C}$ in sealed plastic no more than 7 days before using.

The surface of the agar should be dry before use.

4. No drops of water should be visible on the surface of the agar when the plates are used. Plates must not be over-dried.

\subsubsection{Determination of resistance/susceptibility}

1. Incubate vegetative cells of each $P$. larvae strain to be tested on MYPGP agar for $48 \mathrm{~h}$ at $36^{\circ} \mathrm{C} \pm 1$.

2. Suspend the cells directly from MYPGP in screw capped tubes containing sterile distilled water or sterile saline.

3. Adjust the bacterial suspension until the $O D_{620}$ is in the range of 0.4. Alternatively, individual colonies of each strain can be incubated at $36^{\circ} \mathrm{C} \pm 1$ in $2 \mathrm{ml}$ aliquots of MYPGP broth for 26 to $75 \mathrm{~h}$ until the $\mathrm{OD}$ is in the range of 0.5 . Optimally, use the adjusted suspension within $15 \mathrm{~min}$ of preparation and always within $60 \mathrm{~min}$.

4. Vortex for 3 minutes.

5. Dip a sterile cotton swab in the bacterial suspension and remove excess fluid on the swab by turning it against the inside of the tube.

6. Spread the inoculum evenly over the entire surface of the plate prepared in 3.6.2.2. by inoculating in three directions.

7. Place antibiotic discs (pre-warmed to RT) on the plate. Discs should be in firm, even contact with the surface of the medium. At least three replications for each bacterial strain is recommended. It is possible to apply more than one disc per plate; in this case, discs should be spaced so that zones of inhibition in susceptible isolates do not overlap. Overlapping will impede the measurement of zone diameters.

8. Apply the "15-15-15 rule": Use the inoculum within 15 min of preparation and never beyond $60 \mathrm{~min}$. Apply discs within 15 min of inoculating plates. Start incubation within $15 \mathrm{~min}$ of application of discs.

9. Incubate the plates inverted at $36^{\circ} \mathrm{C} \pm 1$ during $72 \mathrm{~h}$.

10. Measure the resulting inhibition zone (clear area without bacterial growth including the disc) by using a calliper or an automated zone reading. Read the plates from the back against a black background illuminated with reflected light.

11. A correct inoculum and satisfactorily spread plates will result in a confluent lawn of growth in the absence of antibiotic. It is important that there is an even lawn of growth to achieve uniformly circular inhibition zones. If individual colonies can be seen, the inoculum is too light and the test must be repeated. In case of distinct colonies within zones, subculture the colonies, check purity and repeat the test if necessary.

Interpretation: for tetracyclines, an inhibition zone of less than 20 $\mathrm{mm}$ in diameter (including the disc) is considered as the separation point between resistant and susceptible strains as follows: "resistant" $\leq 14 \mathrm{~mm}$; "intermediate": between 15-19 mm and "susceptible": $\geq 20$ mm (Alippi et al., 2007).

It is strongly recommended to use reference standard strains according to the indications of NCCLS or EUCAST with the only difference that MYPGP agar (see section 3.1. for recipe) should be used as basal medium.

\section{Experimental infection}

\subsection{Infection of in vitro reared larvae for the analysis of virulence and pathomechanisms of Paenibacillus larvae}

Exposure bioassays (Genersch et al., 2005) are a reliable approach to determine virulence of different $P$. larvae strains in the laboratory. Briefly, this experiment consists in:

1. Rear first-instar larvae from various colonies in 24-well plates, with 10 larvae per well.

2. Provide larvae with larval food mixed with a determined quantity of infectious spores during the first 24 hours. Afterwards, larvae will receive normal food every day for the rest of the experiment. A control group receives normal larval diet throughout.

3. Each day dead larvae are recorded and examined for AFB infection. 
Table 4. Estimated $\mathrm{LC}_{50}$ and $\mathrm{LT}_{100}$ values (min-max) for ERIC I and ERIC II. (Genersch et al., 2005).

\begin{tabular}{|l|l|l|}
\hline Genotype & LC $_{\mathbf{5 0}}{\text { (CFU } \mathbf{~}^{-\mathbf{1}} \text { larval diet) }}^{\text {LT }} \mathbf{L T}_{\mathbf{1 0 0}}$ (days p.i.) \\
\hline ERIC I & $<<100-800$ & $7-10$ \\
\hline ERIC II & $<<100-620$ & $10-138.9$ \\
\hline
\end{tabular}

Spore preparations for experimental infection can be performed as described under section 3.4. or as described below (Genersch et al., 2005):

1. Resuspend around $100 P$. larvae colonies in $300 \mu$ of brain heart infusion broth (BHI).

2. Inoculate on Columbia sheep blood agar (CSA) slants.

3. Incubate slants containing bacterial suspension at $37^{\circ} \mathrm{C}$ for 10 days or until sporulation has occurred.

4. Collect medium containing spores.

5. Calculate spore concentration in the medium in colony forming units after plating different dilutions of the collected medium.

6. Count colonies after 6 days of incubation.

\subsubsection{Protocol for exposure bioassays}

1. For grafting of larvae, dispense $300 \mu \mathrm{l}$ of larval feed per well in a 24-well plate. Leave 6 wells empty (A1, A3, A5, D2, D4 and D6) and fill them with $500 \mu$ lof double distilled water to avoid desiccation.

2. Incubate plates $30 \mathrm{~min}$ at $35^{\circ} \mathrm{C}$ to warm them up.

3. Graft the larvae by inserting a grafting tool under the back of the larvae floating in royal jelly without touching it, and carefully deposit it on the surface of the larval feed prepared in the well plate. Deposit ten larvae per well. Note: Graft only L1 instar larvae, under 12 hours of age from hatching. Collecting larvae from as many different populations as possible will ensure randomization, achieve homogenous treatment groups, and avoid population-specific variations.

4. For starting the experimental phase, aliquot larval feed and add the necessary volume of spore suspension, which needs to contain a defined concentration of spores to adjust a defined final spore concentration in the larval feed, e.g., to the desired lethal concentration (LC) for the infection group (Table 4).

5. Dispense $300 \mu \mathrm{l}$ per well of the spore-contaminated larval diet in 3 different wells. Leave 3 wells for the control group receiving non-spore contaminated larval diet during the entire experiment.

6. Set ten larvae per well.

7. Incubate plates at $35^{\circ} \mathrm{C}$ for 24 hours.

8. Groups of 30 larvae (in 3 wells) are treated as one replicate and at least three independent replicates should be performed for statistical analysis (see the BEEBOOK paper on statistics (Pirk et al., 2013)).
9. After 24 hours of infection, transfer larvae to a pre-warmed, fresh normal larval diet plate.

Use a different grafting tool for each treatment group to avoid reinfection. Thereafter, every treatment group receives fresh larval diet every 24 hours.

10. Analyze the plates each day under a stereo microscope to determine the health status of the larvae.

11. Transfer remaining (living) larvae to a new plate containing pre-warmed fresh larval diet.

12. Proceed with experiment until day 14. Since larvae increase in size during the experiment, the number of larvae per well must be decreased accordingly.

13. After defecation (at day 7-8, when light yellow secretion can be observed surrounding the larvae), transfer larvae to pupation plates. Prepare pupation plates by lining every well with laboratory tissues, leaving 6 wells free for double distilled water.

14. Larvae are classified as dead when they stop breathing (movement of tracheal openings stops) and lose body elasticity. The number of dead larvae should be reported every day.

15. To determine whether $P$. larvae infection caused the death of a larva, dead larvae are plated out on Columbia sheep blood agar (CSA) plates. Plates are incubated overnight at $37^{\circ} \mathrm{C}$ to allow the growth of vegetative bacteria only (spores need about 3 days to germinate under these conditions). Positive AFB infection will be confirmed by growth of $P$. larvae (see section 3.2.).

16. Further confirmation is provided by performing $P$. larvae specific PCR-analysis of colonies grown from larval remains.

16.1. Pick one colony.

16.2. Dissolve it in $25 \mu \mathrm{l}$ of double distilled water.

16.3. Boil at $95^{\circ}$ for 10 minutes.

16.4. Centrifuge for 10 minutes at 9,500 rcf.

16.5. Supernatant can be used as template for PCR (see section 3.2.2.).

\subsubsection{Analysis of generated data}

In order to evaluate compiled experimental data, two different analyses to measure virulence can be performed. The first virulence indicator is the lethal concentration (LC) value (Thomas and Elkinton, 2004), which indicates the spore concentration at which $50 \%\left(\mathrm{LC}_{50}\right)$ or $100 \%\left(\mathrm{LC}_{100}\right)$ of the individuals are killed. To calculate this measure, the proportion of dead larvae from the number of exposed larvae is plotted against spore concentration. From such graphs, one can to estimate the spore concentration needed to kill a given proportion of the exposed population. These graphs also allow to deduce - for a certain analysed strain - the approximate spore concentration present when a specific percentage of the exposed population is dead. 
Another measure of virulence is the lethal time (LT) (Thomas and Elkinton, 2004) which is the time it takes the pathogen to kill 50\% $\left(\mathrm{LT}_{50}\right)$ or $100 \%\left(\mathrm{LT}_{100}\right)$ of the infected animals. In order to obtain this measure, the time course of infection must be determined.

Cumulative mortality per day is calculated as percentage of all individuals which died from $P$. larvae infection during the course of the experiment (total number of $P$. larvae-killed animals until the end of the experiment). Average values are calculated every day from at least three independent replicates, and plotted against every time point (day post-infection).

\subsection{Experimental infection of a bee colony}

Colony assays of AFB prevalence can be used to determine the efficacies of antibiotics and other treatments as well as the resistance traits of specific colonies.

\subsubsection{Inoculation with known spore concentration solution}

Below is one protocol for a field evaluation of AFB prevalence, derived from Evans and Pettis (2005):

1. Establish clean colonies of equal strength by placing $1.2 \mathrm{~kg}$ of worker bees and a marked queen (from resistant or susceptible stock, if desired) into a standard (e.g. Langstroth) hive body.

2. Following establishment and the initiation of brood rearing (ca. 1 month), inoculate each colony twice (2-4 weeks apart) with spores from a fresh field isolate of $P$. larvae.

3. Inoculate by spraying approximately 2,000 immature bees (eggs, embryos, and first-and second-instar larvae) with a sucrose-water (1:10 weight/volume) suspension containing ca. 200 million $P$. larvae spores.

Sufficient inoculant for $>50$ colonies is prepared by macerating and suspending ca. 100 scales (dried larval remains) collected from symptomatic colonies.

4. Spray inoculation is effective at initiating AFB infection in colonies, with ca. $50 \%$ of managed colonies exhibiting AFB disease one month following a single inoculation, and nearly all of susceptible colonies showing symptoms by three weeks after the second inoculation.

\subsubsection{Inoculation with diseased brood}

If it is not important to inoculate colonies with a known quantity of spores (e.g. if the goal of the experiment is simply to induce clinical symptoms of AFB), a comb section ( $15 \mathrm{~cm} \times 15 \mathrm{~cm}$ ) can be cut from frames containing infective AFB scales (dried spores). At least $50 \%$ of the cells should contain scale. Introduce the comb sections with AFB scale into the middle frame in each colony.

\subsection{Measuring colony resistance to AFB}

\subsubsection{Surveying inoculated colonies}

1. Inspect colonies every two weeks to assess disease levels and colony growth, and to ensure that all colonies were successfully inoculated.

2. Approximately 90 days after colony establishment, colony growth can be measured by removing individual frames and estimating the area of sealed immature brood (see the $B E E B O O K$ paper on methods for estimating strength parameters (Delaplane et al., (2013)). Simultaneously, the level of foulbrood disease can be determined by making a visual inspection of all brood (immature larval and pupal honey bees) for evidence of infection. Severity of AFB infection can be quantified using a modification of a standard scoring method (Hitchcock et al., 1970). Each frame with brood is rated on a 0-3 scale as to AFB infection:

- $0=$ no visible signs of disease

- $1=$ less than 10 cells/frame with visible AFB

- $2=11-100$ cells with AFB

- $3=$ greater than 100 cells with AFB

A composite disease score is then generated by summing across all frames for each colony.

3. An overall severity score for each colony on each inspection date can be obtained by calculating the mean ( \pm s.d.) of the individual frame scores. An overall score of 1 corresponds to a colony with only slight clinical symptoms, possibly not noted by cursory inspection. An overall score of 2 would indicate noticeable symptoms, and a score of 3 corresponds to a highly symptomatic colony.

\subsubsection{Colony resistance}

It is important to test the viability of the AFB spores used to challenge the colony. A lack of clinical symptoms after challenge may be due to colony resistance (Spivak and Reuter, 2001) or the use of non-viable spores.

- An indirect way to test for colony resistance to AFB is to assay the colony for hygienic behaviour using the $24 \mathrm{~h}$ freeze-killed brood test, as outlined in the BEEBOOK paper on queen rearing and selection (Büchler et al., 2013). Colonies that remove $>95 \%$ of the freeze-killed brood within 24 hours, over two repeated tests, are likely to demonstrate resistance to AFB.

- It has not been established whether colonies that remove $>95 \%$ of pin-killed brood (another assay for hygienic behaviour) are also likely to be resistant to AFB. This needs to be tested. 


\section{5. 'omics and other sophisticated techniques}

\subsection{Paenibacillus larvae gene expression}

$P$. larvae gene expression under different experimental conditions can be investigated at the transcriptional level by making use of quantitative reverse transcriptase polymerase chain reactions (qRT-PCR). The state-of-the-art-analysis of qRT-PCR data relies on normalized and calibrated relative quantities (Vandesompele et al., 2002; Hellemans et al., 2007). In order to normalize the qRT-PCR data on target genes, normalization factors (NFs), based on the geometric mean of converted threshold cycle values (Ct-values), need to be calculated for each sample. Before calculating NFs, one has to decide how many reference genes should be included in this calculation. This decision is based on the expression stability of candidate reference genes under all examined experimental conditions. Therefore, the protocol below describes how to select reference genes for $P$. larvae.

\subsubsection{Reference gene selection}

\subsubsection{Sample collection and storage}

1. Grow at least ten independent $P$. larvae cultures for each condition to be analysed with qRT-PCR.

2. Centrifuge cultures for $5 \mathrm{~min}$ at $8,000 \mathrm{xg}$ and $4^{\circ} \mathrm{C}$.

3. Pour off the supernatant.

4. Resuspend the bacterial pellet in RNA/ater solution (Ambion).

5. Incubate for approximately half an hour on ice.

6. Divide the suspension in aliquots.

7. Centrifuge aliquots for $2 \mathrm{~min}$ at $8,000 \mathrm{xg}$ and $4^{\circ} \mathrm{C}$.

8. Store at $-80^{\circ} \mathrm{C}$.

\subsubsection{RNA and CDNA preparation}

1. Centrifuge thawed aliquots for $2 \mathrm{~min}$ at $6,500 \times \mathrm{g}$ and $4^{\circ} \mathrm{C}$.

2. Resuspend bacterial pellets in TE buffer with Lysozyme ( 15 $\mathrm{mg} / \mathrm{ml}$ ) and Proteinase K (Qiagen).

3. Vortex for $10 \mathrm{sec}$.

4. Incubate 10 min at RT with constant shaking.

5. Isolate RNA with RNeasy Plus Mini Kit and protocol "Purification of Total RNA for Animal Cells" (with on-column DNase I treatment).

6. Elute RNA with $30 \mu \mathrm{l}$ RNase-free water.

7. Store at $-80^{\circ} \mathrm{C}$

8. Convert RNA to CDNA with RevertAid First Strand CDNA Synthesis Kit (Fermentas), using random hexamer primers.

\subsubsection{Primer design and secondary structures}

- Design primers (80 - 150 bp) with Primer3Plus (Untergasser et al., 2007).

- Evaluate secondary structures of amplicon with MFold (Zuker 2003) for $60^{\circ} \mathrm{C}, 50 \mathrm{mM} \mathrm{Na}^{+}$and $3 \mathrm{mM} \mathrm{Mg}^{2+}$. Selected candidate reference genes for $P$. larvae are listed in Table 5 .

\subsubsection{4. $q R T-P C R$ reactions}

For a single reaction, assemble the following components (total volume: $15 \mu \mathrm{l} /$ reaction):

- $7.5 \mu$ l 2x Platinum SYBR Green qPCR SuperMix-UDG (Invitrogen)

- $0.03 \mu \mathrm{l}$ of $100 \mu \mathrm{M}$ forward and reverse primer each

- $1.0 \mu \mathrm{l}$ cDNA template

- $6.5 \mu \mathrm{l}$ distilled water

\subsubsection{5. $q R T$-PCR program}

Set program as follows:

- $50^{\circ} \mathrm{C}, 2$ min, 1 cycle

- $95^{\circ} \mathrm{C}, 2$ min, 1 cycle

- $\left[95^{\circ} \mathrm{C}, 20 \mathrm{sec} ; 60^{\circ} \mathrm{C}, 40 \mathrm{sec}\right] 40$ cycles

After PCR amplification, perform a melt curve analysis by measuring fluorescence after each temperature increase of $0.5^{\circ} \mathrm{C}$ for $5 \mathrm{sec}$ over a range from $65^{\circ} \mathrm{C}$ to $95^{\circ} \mathrm{C}$.

\subsubsection{6. $q R T-P C R$ analysis}

Analyze the reference gene stability with geNorm ${ }^{\text {PLUS }}$ within qBase ${ }^{\text {PLUS }}$ (Vandesompele et al., 2002; Hellemans et al., 2007) using targetspecific amplification efficiencies.

\subsubsection{Differential gene expression}

Sample collection and storage (except for the recommendation of ten cultures), RNA and CDNA synthesis, in silico primer design and secondary structure evaluation, and qPCR experimental procedures (reactions, program and analysis, except for geNormPLUS analysis) are essentially the same for the study of differential gene expression by qRT-PCR as described in section 5.1.1. for reference gene selection.

\subsection{Comparative genome analysis within the species Paenibacillus larvae using suppression subtractive hybridization}

Suppression subtractive hybridization (SSH) is a powerful tool for elucidating genomic sequence differences among closely related bacteria. SSH is a PCR-based DNA subtraction method which was originally developed for generating differentially regulated or tissuespecific CDNA probes and libraries (Diatchenko et al., 1996). However, it has also been successfully adapted for bacteria, especially for the identification of genes that contribute to the virulence of bacterial organisms (Akopyants et al., 1998). For example, SSH has been successfully employed to compare genomes of pathogenic and nonpathogenic (Janke et al., 2001; Reckseidler et al., 2001) or virulent and avirulent strains of bacterial pathogens (Zhang et al., 2000). SSH has also led to the identification of pathogenicity islands (Hacker et al., 1997) in infectious bacteria (Agron et al., 2002). Recently, SSH analysis of all four genotypes of $P$. larvae led to the identification of putative virulence factors like potent antibiotics belonging to the class 
Table 5. Reference genes for $P$. larvae.

\begin{tabular}{|c|c|c|}
\hline Name & Sequence & Predicted gene product \\
\hline $\begin{array}{l}\text { AFB_rpoD_fw } \\
\text { AFB_rpoD_rv }\end{array}$ & $\begin{array}{l}\text { 5'-AACTTGCCAAACGGATTGAG-3' } \\
\text { 5'-AAGCCCCATGTTACCTTCCT-3' }\end{array}$ & RNA polymerase sigma factor RpoD \\
\hline $\begin{array}{l}\text { AFB_gyrA_fw } \\
\text { AFB_gyrA_rv }\end{array}$ & $\begin{array}{l}\text { 5'-ATGCGGTCATCCCTATTGAG-3' } \\
\text { 5'-GGTCATCTTCCCGCAAATTA-3' }\end{array}$ & DNA gyrase subunit $A$ \\
\hline $\begin{array}{l}\text { AFB_cmk_fw } \\
\text { AFB_cmk_rv }\end{array}$ & $\begin{array}{l}\text { 5'-GTACAGGGCGATTACCTGGA-3' } \\
\text { 5'-GCCATCAACGAATACCTGCT-3' }\end{array}$ & Cytidylate kinase \\
\hline $\begin{array}{l}\text { AFB_sucB_fw } \\
\text { AFB_sucB_rv }\end{array}$ & $\begin{array}{l}\text { 5'-ATTGCCAAGGGTGTTGTAGC-3' } \\
\text { 5'-TTCAGCCCGGATTCATTTAG-3' }\end{array}$ & Succinyl-CoA synthetase subunit $\beta$ \\
\hline $\begin{array}{l}\text { AFB_eftu_fw } \\
\text { AFB_eftu_rv }\end{array}$ & $\begin{array}{l}\text { 5'-TAACATCGGTGCCCTTCTTC-3' } \\
\text { 5'-CCACCCTCTTCGCTAGTCAG-3' }\end{array}$ & Elongation factor $\mathrm{Tu}$ \\
\hline $\begin{array}{l}\text { AFB_fum _fw } \\
\text { AFB_fum_rv }\end{array}$ & $\begin{array}{l}\text { 5'-CCAAAATATGCGGAGCTGAT-3' } \\
\text { 5'-GTGAACCGCAATTTCCCTTA-3' }\end{array}$ & Fumarate hydratase \\
\hline $\begin{array}{l}\text { AFB_purH_fw } \\
\text { AFB_purH_rv }\end{array}$ & $\begin{array}{l}\text { 5'-TTCTCTCGGGGCTITTGATA-3' } \\
\text { 5'-CTACTGTTGGCTCACGGTCA-3' }\end{array}$ & $\begin{array}{l}\text { Bifunctional phosphoribosyl aminoimidazole } \\
\text { carboxamide formyltransferase / IMP cyclohydrolase }\end{array}$ \\
\hline $\begin{array}{l}\text { AFB_adk_fw } \\
\text { AFB_adk_rv }\end{array}$ & $\begin{array}{l}\text { 5'-TCAACAGGTGATGCTITTCG-3' } \\
\text { 5'-TGTGATTTCGTCAGGAACCA-3' }\end{array}$ & Adenylate kinase \\
\hline $\begin{array}{l}\text { AFB_gapdh_fw } \\
\text { AFB_gapdh_rv }\end{array}$ & $\begin{array}{l}\text { 5'-TGTTGAAGCTGGTGAAGGTG-3' } \\
\text { 5'-TCCGCTाாTCTाTTGCAGT-3' }\end{array}$ & Glyceraldehyde-3-phosphate dehydrogenase \\
\hline
\end{tabular}

of non-ribosomal peptides and polyketides as well as several toxins and cytolysins (Fünfhaus et al., 2009).

The principle of any SSH analysis is that one genome putatively containing additional genes (the so-called 'driver') is subtracted from the other genome ('tester') with the result that the additional sequences specific to the tester remain and can be visualized via PCR. For SSH analysis, genomic DNA of $P$. larvae grown in liquid culture of brain heart infusion broth (BHI broth, see section 3.1. for recipe) is used. Since the quality of the genomic DNA is of crucial importance, special kits for DNA extraction of Gram-positive bacteria (e.g. MasterPure Gram Positive DNA Purification Kit, Epicentre Biotechnologies) to isolate $P$. larvae DNA are recommended. The following protocol for SSH is based on the protocols published by Akopyants et al. (1998) using the PCR-Select Bacterial Genome Subtraction Kit (BD Clontech). SSH consists of two consecutive phases, the hybridization and the amplification. Within the phase of hybridization, the genomic DNA extracted from the 'driver' strain is hybridized with DNA extracted from the 'tester' strain. Sequences that are present in the tester strain but missing in the driver strain are then isolated in the amplification phase in which target genomic DNA fragments are amplified, while amplification of non-target DNA is simultaneously suppressed using the suppression PCR effect (Siebert et al., 1995).

The protocol for the comparison of $P$. larvae genotypes involves the following steps:

1. Following the manufacturer's protocol, digest the isolated DNA from both genomes using restriction enzyme $R s a I$, which has a recognition sequence of only four bases.

Since this sequence occurs often in the genome of $P$. larvae, a high fragmentation of the bacterial DNA (100 to $1000 \mathrm{bp}$ ) with blunt ends is achieved.

2. After purification of the fragmented DNA with the MinElute Cleanup Kit (QIAGEN) according to the manufacturer's protocol, divide the DNA of the tester strain into two pools which are ligated with either Adaptor 1 (5'-

CTAATACGACTCACTATAGGGCTCGAGCGGCCGCCCGGGCAGGT-

$\left.3^{\prime}\right)$ or Adaptor 2R (5'-

CTAATACGACTCACTATAGGGCAGCGTGGTCGCGGCCGAGGT-3'), catalysed by T4 DNA ligase.

The ends of the adaptors lack a phosphate group, so only one strand of each can be ligated to the $5^{\prime}$ end of the tester DNAs.

3. For the first round of hybridization, mix each pool of adaptorligated tester-fragments with a 50-100-fold excess of driverfragments.

4. Incubate the mixed samples at $98^{\circ} \mathrm{C}$ for $90 \mathrm{sec}$. (denaturation).

5. Incubate at $65^{\circ} \mathrm{C}$ for 90 min (annealing).

6. In the second round of hybridization, mix both pools without denaturation.

7. Incubate overnight at $65^{\circ} \mathrm{C}$ to allow free tester-fragments from both pools to form heterohybrids (hybridization of complementary tester DNAs with different adaptors (Akopyants et al., 1998)).

8. Add freshly denatured driver to the mixture. 
9. Allow the samples to hybridize.

During this step, hybrid molecules are formed, but only DNA fragments which are exclusively present in the sample of the tester strain are amplified in the subsequent amplification phase.

10. For amplification, perform a nested PCR with adaptor specific primers.

For the first PCR, the primer 1 (5'-

CTAATACGACTCACTATAGGGC-3') is used. For the second PCR, the nested primer 1 (5'-TCGAGCGGCCGCCCGGGCAGGT-3') and the nested primer 2R (5'-AGCGTGGTCGCGGCCGAGGT-3') are used.

11. To obtain a library of tester-specific sequences, secondary PCR products - i.e., clone tester specific DNA fragments - are then cloned into appropriate vectors (e.g. pCR2.1TOPO vector, Invitrogen, containing an ampR gene).

12. Transform into competent E. coli (e.g. TOP10 cells, Invitrogen) following the manufacturer's instructions.

13. Plate transformation mixes on agar plates supplemented with Ampicillin $(100 \mu \mathrm{g} / \mathrm{ml})$

14. Incubate overnight at $37^{\circ} \mathrm{C}$.

15. Pick and grow clones individually overnight in Luria broth in the presence of Ampicillin $(100 \mu \mathrm{g} \mathrm{ml} / \mathrm{ml})$ at $37^{\circ} \mathrm{C}$ and 300 rpm.

16. Extract plasmid DNA from these overnight cultures (e.g. by using the Qiagen plasmid mini kit).

17. The presence of inserted $P$. larvae DNA can be verified by restriction digestion. In the case of pCR2.1TOPO, perform digestion with ECORI.

18. Sequence detected inserts from positive clones using appropriate primers.

For PCR2.1TOPO, use primers M13 uni (-21)

5'-TGTAAAACGACGGCCAGT-3' and M13 rev (-29)

CAGGAAACAGCTATGACC.

19. To verify the specificity of the DNA fragments for the tester strain, perform a PCR with fragment specific PCR primers on DNA from the tester strain and related $P$. larvae strains (i.e., representatives of the same genotype).

In each subtraction, all controls recommended by the manufacturer must be performed and all must test positive. Analysis of the tester-specific sequences is performed with BLASTx (Altschul et al., $1990,1997)$ followed by functional annotation based on the COG (cluster of orthologous groups) classification (Tatusov et al., 1997, 2003).

\subsection{Conventional proteomics using two- dimensional gel electrophoresis}

Genomic sequences are not sufficient for explaining biological functions because there is no strict linear correlation between the genome and the proteome of an organism. For example, protein modifications and relative concentration of proteins cannot be determined by genomic analysis (Pandey and Mann, 2000). Furthermore, the DNA sequences give no information about conditions and time for translation as well as effects of up or down regulation of gene expression (Humphery-Smith et al., 1997). Therefore, predictions on the basis of genetic information should be completed by expression data at the level of the transcriptome and the proteome. By means of proteome analysis, a holistic approach of protein expression under specific conditions is possible. The classical method of proteomics is the two-dimensional (2D) gel electrophoresis (O'Farrell, 1975; Klose, 1975). Recently, it was successfully used for a comparison of the $P$. larvae genotypes ERIC I and II (Fünfhaus and Genersch, 2012).

Sample preparation for 2D electrophoresis uses the following protocol (Fünfhaus and Genersch, 2012):

1. Cultivate $P$. larvae strains to be analysed on Columbia sheep blood agar (CSA; see section 3.1. for recipe) plates for three days at $37^{\circ} \mathrm{C}$.

2. To obtain a pre-culture, inoculate $3 \mathrm{ml}$ brain heart infusion broth (BHI, see section 3.1 for recipe) with one bacterial colony and the cells are grown overnight at $37^{\circ} \mathrm{C}$ with shaking at $200 \times \mathrm{g}$.

3. To obtain a $10 \mathrm{ml}$ main culture, inoculate $9 \mathrm{ml} \mathrm{BHI}$ with a preculture to achieve a final $\mathrm{OD}_{600}$ of 0.01 after adjustment to a final volume of $10 \mathrm{ml}$ with $\mathrm{BHI}$.

4. Incubate at $37^{\circ} \mathrm{C}$ with shaking at $200 \times \mathrm{g}$.

5. Monitor growth continuously by measuring $\mathrm{OD}_{600}$.

6. Stop growth in the late exponential phase $\left(\mathrm{OD}_{600} 0.65\right)$ by harvesting the cells via centrifugation $\left(20 \mathrm{~min}, 5,000 \times \mathrm{g}, 4^{\circ} \mathrm{C}\right)$.

7. Wash the bacterial cell pellets three times with ice-cold PBS.

8. Resuspended in $1 \mathrm{ml}$ lysis buffer ( $7 \mathrm{M}$ urea, $2 \mathrm{M}$ thiourea, $4 \%$ (w/v) CHAPS, complete protease inhibitor cocktail (Roche)).

9. Disrupt cells by using a sonicator, e.g. ranson Sonifier 250 (duty control: 10\%; output control: 1 ). Repeated sonication cycles (ten times for $30 \mathrm{sec}$ ) are interrupted by cooling phases for $60 \mathrm{sec}$.

10. Incubate samples for $1 \mathrm{~h}$ at RT to facilitate dissolving the proteins.

11. Separate crude protein extracts from cellular debris by centrifugation at $16,100 \times \mathrm{g}$ for $25 \mathrm{~min}$ at $4^{\circ} \mathrm{C}$.

The resulting supernatant contains the cytosolic proteins but also salts and other small charged molecules which need to be removed from the solution by precipitation.

12. Precipitate the cytosolic proteins of $P$. larvae with one volume $20 \%$ TCA, $2 \%$ Triton $X-100$ overnight at $4^{\circ} \mathrm{C}$.

13. Pellet the precipitated proteins by centrifugation $(16,100 \times \mathrm{g}$, $25 \mathrm{~min}, 4^{\circ} \mathrm{C}$ ).

14. Wash the pellets with $80 \%$ acetone to remove residual TCA. 
15. Resuspend the washed pellet in $200 \mu$ sample buffer ( $7 \mathrm{M}$ urea, 2M thiourea, 4\% (w/v) CHAPS, 100 mM DTT, 1\% Bio-Lyte Ampholyte (Bio-Rad), complete protease inhibitor cocktail (Roche)).

16. Vortex for $1 \mathrm{~h}$ at RT.

17. Separate the insoluble material from the soluble proteins by centrifugation $\left(15,000 \times \mathrm{g}, 1 \mathrm{~h}, 15^{\circ} \mathrm{C}\right)$ to obtain the soluble cytoplasmic fraction.

18. Determine the protein concentration by performing the Pierce ${ }^{\circledR} 660 \mathrm{~nm}$ Protein Assay (Thermo Scientific) according to the manufacturer's protocol.

19. Store samples at $-80^{\circ} \mathrm{C}$ until further analysis. These protein samples are then subjected to 2D-gel electrophoresis with the isoelectric focussing (IEF) as the first dimension followed by SDS-PAGE analysis as second dimension.

20. Dilute the samples with rehydration buffer (7 M urea, $2 \mathrm{M}$ thiourea, 1\% (w/v) CHAPS, 10 mM DTT, 0.25\% Bio-Lyte Ampholyte (Bio-Rad)).

21. Determine the amount of protein to load on IPG strip according to the sample, the $\mathrm{pH}$ range, the length of the IPG strip and the staining method.

22. Focussing of proteins is best performed in commercially available, immobilized pH gradient strips (IPG strips) selecting a suitable $\mathrm{pH}$ gradient. For the analysis of $P$. larvae proteins IPG strips with a pH gradient 5-8 and a length of $7 \mathrm{~cm}$ (Bio-Rad) proved to be useful.

23. Load $60 \mu \mathrm{g}$ cytosolic $P$. larvae proteins in a total rehydration volume of $125 \mu$ l on the IPG strips.

The following protocol for IEF is adapted to the PROTEAN IEF Cell (Bio-Rad) at $20^{\circ} \mathrm{C}$ :

24. Load the samples on the IPG strips by an active in-gel rehydration for $18 \mathrm{~h}$ at $50 \mathrm{~V}$ followed by a voltage profile with increasing values:

- linear increase from 50-200 V for $1 \mathrm{~min}$.

- $200 \mathrm{~V}$ for $200 \mathrm{Vh}$.

- linear increase from $200-500 \mathrm{~V}$ for $1 \mathrm{~min}$.

- $500 \mathrm{~V}$ for $500 \mathrm{Vh}$.

- linear increase from $500-1000 \mathrm{~V}$ for $1 \mathrm{~min}$.

- $1000 \mathrm{~V}$ for $1000 \mathrm{Vh}$.

- linear increase from $1000-2000 \mathrm{~V}$ for $1 \mathrm{~min}$.

- $2000 \mathrm{~V}$ for $2000 \mathrm{Vh}$.

- linear increase from $2000-4000 \mathrm{~V}$ for $1 \mathrm{~min}$.

- $4000 \mathrm{~V}$ for $4500 \mathrm{Vh}$.

25. Subsequently, saturate the proteins separated in the IEF gel with SDS by equilibrating the IPG strips in equilibration buffer I (6M urea, 30\% (v/v) glycerol, 5\% (w/v) SDS, $0.05 \mathrm{M}$ Tris $\mathrm{pH}$ $8.8,1 \%(w / v)$ DTT) for $10 \mathrm{~min}$.
26. Block free $\mathrm{SH}$-groups of the separated proteins by equilibrating the IPG strips in equilibration buffer II (6M urea, $30 \%$ (v/v) glycerol, 5\% (w/v) SDS, 0.05 M Tris pH 8.8, 5\% (w/v) iodoacetamide) for $10 \mathrm{~min}$.

27 . For the SDS-PAGE as second dimension a $12 \%$ polyacrylamide gel run at $35 \mathrm{~mA}$ in a PROTEAN II XL Cell (Bio-Rad) proved to be suitable.

28. Gels are stained with Coomassie (Page Blue Protein Solution, Fermentas) according to standard protocol (see the BEEBOOK paper on physiological and biochemical methods (Hartfelder et al., 2013)).

Analysis of the $2 \mathrm{D}$ gels can be performed by using software PDQuest 8.0 (Bio-Rad). Protein identification can be achieved by mass spectrometric analysis followed by comparison of peptide masses and sequence information of the sample with different databases (see the $B E E B O O K$ paper on physiological and biochemical methods (Hartfelder et al., 2013) and the BEEBOOK paper on chemical ecology (Torto et al., 2013)).

\subsection{Differential proteomics of Paenibacillus larvae}

Liquid chromatography coupled directly to mass spectrometry provides another means for monitoring a proteome or changes in a proteome. Such global monitoring of changes in levels of proteins in response to a stimulus (e.g. a pathogen such as $P$. larvae) can provide very direct insight into the molecular mechanisms employed to respond to that challenge. For example, bee larvae up-regulate expression and activation of phenoloxidase in response to a $P$. larvae challenge (Chan et al., 2009). Mass spectrometry is currently the favoured detection method for monitoring the entire protein component of a system (i.e. the proteome), and various methods exist for comparing protein expression in one state to that in another. The most quantitative approach involves the use of stable isotopes to introduce a 'mass tag' into the proteins from two or more different conditions and then in subsequent mass spectrometric analyses, the intensities of the differently tagged forms reflect the relative quantities in the original sample. Several such labelling methods exist and are reviewed elsewhere (Ong et al., 2003), so here we focus on the method that has been used most extensively in honey bee proteomics. It involves the reductive dimethylation of primary amines in peptides using formaldehyde isotopologues.

Assumptions: a suitable, controlled experiment should be designed to compare untreated bees/cells to equivalent samples treated with a stimulus or challenged with a pathogen. If the following steps cannot be carried out immediately, then samples can typically be stored as a cell pellet, tissue, or whole bee at $-80^{\circ} \mathrm{C}$ for weeks or months without protein degradation. 


\subsubsection{Sample preparation}

\subsubsection{Extract proteins}

Extract proteins into $50 \mathrm{mM} \mathrm{NH}_{4} \mathrm{HCO}_{3}(\mathrm{pH} 8.0)$ with $1 \%$ sodium deoxycholate ( $A B C / D O C)$.

Option 1: For cultured or primary cells:

1. Wash cells first in PBS.

2. Pellet at $600 \mathrm{xg}$.

3. Remove supernatant.

4. Solubilize the pellet in $\mathrm{ABC} / \mathrm{DOC}$ at a ratio of $100 \mu \mathrm{l}$ per $2 \mathrm{E}+07$ cells.

The final protein concentration, measured by the BCA method, should be approximately $1 \mu \mathrm{g} / \mu \mathrm{l}$.

Option 2: For any bee tissues:

1. Place the material in a beadmill tube with enough $6 \mathrm{M}$ urea, $2 \mathrm{M}$ thiourea and $50 \mathrm{mM}$ Tris ( $\mathrm{pH} \mathrm{8.0)}$ to fully immerse the tissue.

2. Pulverize the tissue in a beadmill. Determine the specific conditions empirically for each tissue and beadmill type.

3. After milling, pellet insoluble material at $16,000 \times \mathrm{g}$ for $10 \mathrm{~min}$ at $4^{\circ} \mathrm{C}$.

4. Move the supernatant to a clean tube.

5. Precipitate the proteins in the supernatant by adding four volumes of $100 \%$ ethanol, $20 \mu \mathrm{g}$ of molecular biology-grade glycogen and $50 \mathrm{mM}$ sodium acetate $(\mathrm{pH} 5$, from a $2.5 \mathrm{M}$ stock solution).

6. Allow the solution to stand at RT for $90 \mathrm{~min}$.

7. Pellet the proteins by centrifuging for $10 \mathrm{~min}$ at $16,000 \mathrm{xg}$.

8. Resuspend the pellet from this final step in $A B C / D O C$ to bring the protein concentration to $1 \mu \mathrm{g} / \mu \mathrm{l}$.

\subsubsection{Reduce, alkylate and digest proteins to peptides}

1. For each sample, add $1 \mu \mathrm{g}$ dithiothreitol (from a stock solution of $1 \mu \mathrm{g} / \mu \mathrm{l}$ ) to $50 \mu \mathrm{g}$ total protein.

2. Incubate the solution for $30 \mathrm{~min}$ at $37^{\circ} \mathrm{C}$.

3. Add $5 \mu \mathrm{g}$ iodoaccetamide (from a stock solution of $5 \mu \mathrm{g} / \mu \mathrm{l}$ ).

4. Incubate for $20 \mathrm{~min}$ at $37^{\circ} \mathrm{C}$.

5. Add $1 \mu \mathrm{g}$ trypsin (mass spectrometry-grade, Promega).

6. Incubate overnight at $37^{\circ} \mathrm{C}$

\subsubsection{Clean up peptides}

1. Adjust $\mathrm{pH}$ of overnight digestion to 2 using $10 \%$ acetic acid

2. For each sample, prepare a STAGE tip (Rappsilber et al., 2007) by pushing $20 \mu \mathrm{l}$ methanol through, followed by $20 \mu \mathrm{l} 0.5 \%$ acetic acid.

3. Push $10 \mu \mathrm{g}$ total peptide mass (based on original $50 \mu \mathrm{g}$ input) through the STAGE tip.

4. Wash each tip with $20 \mu \mathrm{l} 0.5 \%$ acetic acid.

5. Elute the peptides from each tip into a clean microfuge tube with $10 \mu \mathrm{l} 80 \%$ acetonitrile, $0.5 \%$ acetic acid.

6. Evaporate the solvent from each sample in a vacuum centrifuge.

\subsubsection{Label peptides with stable isotopes}

1. Add $20 \mu \mathrm{l}$ of $100 \mathrm{mM}$ triethylammonium bicarbonate to each tube of dried peptides.

2. Sonicate for $5 \mathrm{~min}$ to solubilize peptides.

3. Add $20 \mu \mathrm{l}$ of formaldehyde isotopologues to respective samples.

$200 \mathrm{mM} \mathrm{CH}_{2} \mathrm{O}$ (L)-light to the first sample.

$200 \mathrm{mM} \mathrm{C}^{2} \mathrm{H}_{2} \mathrm{O}(\mathrm{M})$ - medium to the second sample. $200 \mathrm{mM}{ }^{13} \mathrm{C}^{2} \mathrm{H}_{2} \mathrm{O}$ - heavy $(\mathrm{H})$ to the third sample).

4. Add $2 \mu \mathrm{l}$ of $1 \mathrm{M}$ light ALD solution (sodium cyanoborohydride) to the first ( $L$ ) sample and second $(M)$ sample.

5. Add $2 \mu \mathrm{l}$ of $1 \mathrm{M}$ heavy ALD solution (sodium cyanoborodeuteride) to the third $(\mathrm{H})$ sample.

6. Sonicate for $5 \mathrm{~min}$.

7. If required, centrifuge for $1 \mathrm{~min}$ at low speed to collect all of the solution at the bottom.

8. Leave at ambient temperature in the dark for $90 \mathrm{~min}$.

9. Add $20 \mu \mathrm{l}$ of $3.0 \mathrm{M} \mathrm{NH}_{4} \mathrm{Cl}$.

10. Leave at ambient temperature in the dark for $10 \mathrm{~min}$.

11. Add acetic acid until $\mathrm{pH}<2.5$.

\subsubsection{Clean up peptides}

1. From the final step in paragraph 5.4.1.4. 'Label peptides with stable isotopes', combine the two (for duplex labelling) or three (for triplex labelling) into a single tube.

2. Repeat all steps from paragraph 5.4.1.3. 'Clean up peptides' above, eluting the peptides in step 5 into a 96 -well microwell plate.

\subsubsection{Mass spectrometry analysis}

1. Analyze the combined sample with at least a two-hour gradient into a liquid chromatography-tandem mass spectrometry system (LC-MS/MS).

Most labs will access such a system through a core facility rather than operating the system themselves. Interested readers are referred elsewhere for details on setting up such a system (Forner et al., 2007).

2. Search the LC-MS/MS data against a protein database using MaxQuant (Cox and Mann, 2008), Proteome Discoverer (from ThermoFisher) or SpectrumMill (from Agilent).

Background on the principles underlying such database searching has been covered elsewhere (Forner et al., 2007). The database should contain all protein sequences from all species that might be in the sample. For example, if the experiment has involved infecting bees with $P$. larvae, the database should contain all $A$. mellifera and all $P$. larvae sequences available from their respective genome project pages in GenBank. The search engines mentioned above should also report the isotope ratios representing the relative amounts of each protein detected among the different samples. 


\subsection{Expression of heterologous proteins in Paenibacillus larvae}

The understanding of phenotypic differences within the species $P$. larvae (Genersch and Otten, 2003; Genersch et al., 2005; Neuendorf et al., 2004; Rauch et al., 2009) and the role of genotype-specific putative virulence factors (Fünfhaus et al., 2009; Fünfhaus and Genersch, 2012) have been hampered by the lack of molecular tools allowing genetic manipulation of this pathogen.

To functionally analyse putative virulence factors during bacterial pathogenesis, the corresponding genes need to be disrupted, manipulated, or labelled for specific visualisation. Likewise, the expression of homologous or heterologous proteins in P. larvae would be a valuable tool to further study the molecular pathogenesis of $P$. larvae infections. Recently, the first protocol for the expression of a foreign protein (green fluorescent protein, GFP) in $P$. larvae has been described (Poppinga and Genersch, 2012). Since GFP expression is one of the most successful molecular tools to specifically label proteins and to visualize them under native conditions (Tsien, 1998), this can be considered a breakthrough in AFB research. Constitutive expression of GFP in $P$. larvae will help to visualize and quantify bacterial cells in larval experiments. Additionally, GFP-fused virulence factors that are expressed during infection can be detected and visualised in and/or outside the bacterial cell.

\subsubsection{Transformation of Paenibacillus larvae}

For this purpose plasmid pAD43-25 (BGSC, Bacillus Genetic Stock Center), carrying the gene sequence for a GFP variant ( $g$ fpmut3a), was transformed into wild type $P$. larvae strains ATCC9545 and 04-309 representing both relevant genotypes ERIC I and ERIC II, respectively (Genersch et al., 2005, 2006). Plasmid pAD43-25 functions as an $E$. coli/Gram-positive shuttle vector and enables bacteria to constitutively express the GFP variant gfpmut3a (Dunn and Handelsman, 1999). High level constitutive expression of mutant GFP in vegetative cells is facilitated by the Bacillus cereus UW85 Pupp promoter upstream of gfpmut3a. Mutant gfpmut3a has an optimal excitation wavelength of $498 \mathrm{~nm}$ and the plasmid contains a chloramphenicol resistance cassette.

The first critical step of the molecular manipulation of $P$. larvae is the uptake of foreign DNA, e. g. plasmid DNA. Because $P$. larvae is a gram-positive bacterium, transformation needs a high voltage electric pulse for a successful uptake of foreign plasmid DNA. For this purpose electrocompetent bacterial cells need to be prepared as described by Murray and Aronstein (2008):

1. Grow $P$. larvae cultures to early exponential phase $\left(\mathrm{OD}_{600}\right.$ 0.3).

2. Harvest by centrifugation.

3. Wash bacterial pellets three times using $0.625 \mathrm{M}$ sucrose.
4. Resuspend the final bacterial pellet in $1 / 500$ of the initial culture volume.

5. Store at $-80^{\circ} \mathrm{C}$ in $40 \mu$ aliquots.

Electrocompetent $P$. larvae cells can then be transformed with a plasmid containing a GFP-gene like pAD43-25 using the following protocol:

1. For pAD43-25 transformation, thaw competent cells at $4^{\circ} \mathrm{C}$.

2. Add $500 \mathrm{ng}$ of pAD43-25 in a maximum volume of $10 \mu \mathrm{l}$.

3. During an incubation time of $15-20$ min gently mix each transformation tube every $5 \mathrm{~min}$.

4. Pulse probes in ice cold $1 \mathrm{~mm}$ electroporation cuvettes (Eppendorf).

5. The best transformation results can be achieved with $9 \mathrm{kV} / \mathrm{cm}$ for representatives of the genotype ERIC I and $10 \mathrm{kV} / \mathrm{cm}$ for representatives of the genotype ERIC II. An average of $1.8 \mathrm{E}+04$ and $1.1 \mathrm{E}+06$ transformants per $0.5 \mu \mathrm{g}$ DNA (3.6E+04 and 2.2E+06 transformants per $\mu \mathrm{g}$ DNA) for ERIC I and ERIC II, is obtained using these conditions.

6. Immediately transfer transformation tubes containing shocked cells to $960 \mu$ pre-warmed MYPGP broth.

7. Incubated at $37^{\circ} \mathrm{C}$ for 16 hours with shaking $(350 \times \mathrm{g})$.

8. Dilute regenerated transformation mixes.

9. Plate on MYPGP agar supplemented with $5 \mu \mathrm{g} / \mathrm{ml}$ chloramphenicol.

10. Incubate agar plates at $37^{\circ} \mathrm{C}$.

11. Determine the number of colony forming units (cfu) after 3 days.

\subsubsection{Detection of GFP-expression}

For GFP detection in the vegetative recombinant $P$. larvae isolates ATCC9545 (ERIC I) + pAD43-25 and P. larvae 04-309 (ERIC II) + pAD43-25, clones can be cultivated and analysed during different stages of growth in liquid MYPGP media (Dingman and Stahly, 1983), supplemented with $5 \mu \mathrm{g} / \mathrm{ml}$ chloramphenicol. In each bacterial stage of growth, $10 \mu$ aliquots of the suspension are analysed bright field microscopically using differential interference contrast (DIC). Fluorescence activity is detected by a FITC filter block (e.g. Nikon Ti-E Inverted Microscope). All stages of growth are analysed and it can be observed that the rate of gfpmut3a expressing $P$. larvae clones remains stable throughout the logarithmic as well as the stationary growth phase, indicating that plasmid pAD43-25 is correctly replicated throughout bacterial growth.

Expression of GFP remained stable even after sporulation and germination. This is an essential prerequisite for using recombinant bacteria in infection assays because only spores can be used for infection, and the vegetative bacteria inside the larvae should still carry and express the introduced gene. 


\subsection{Fluorescent in situ hybridization for the detection of Paenibacillus larvae}

Recently, Yue and collaborators (Yue et al., 2008) described a P. larvae specific method based on a previously described general technique of fluorescence in situ hybridization (FISH) (Moter et al., 1998). FISH methods are based on specific binding of fluorescent-labelled oligonucleotide probes to complementary sequences in fixed and permeabilized sections (Itzkovitz and van Oudenaarden, 2011). This approach provides a highly specific method to visualize $P$. larvae in infected larval histological sections, thereby allowing disease monitoring and observation of the life cycle of the bacterium inside the host. P. larvae FISH methodology uses a specific complementary $P$. larvae 16S rRNA targeted oligonucleotide probe coupled with fluorescein isothiocyanate (FITC), that specifically binds to $P$. larvae rRNA. Since bacterial cells are filled with ribosomes, this technique allows the "staining" of the vegetative bacteria. In order to simultaneously visualize the cytoplasm of larval cells, cyanine Cy3labeled oligonucleotides universally detecting conserved 18S rRNA eukaryotic sequences are used. Finally, 4',6-diamidino-2-phenylindole (DAPI), a fluorescent dye that binds A-T rich regions of DNA, is employed to visualize cell nuclei.

The following protocol provides a method to fix and embed larval tissues, in order to obtain histological sections, as well as for further processing these sections by fluorescence in situ hybridization.

\subsubsection{Preparation and embedding of larval tissues}

1. Perform infection assays as described in section 4.1.

2. Wash each larva for 5 seconds with $100 \%$ ethanol.

3. Fix larvae by overnight incubation with $4 \%$ Roti Histofix (Roth, Karlsruhe) at $4^{\circ} \mathrm{C}$ at $20 \mathrm{rpm}$.

4. Wash samples overnight with $1 \mathrm{X}$ PBS solution containing $6.8 \%$ sucrose under the same conditions.

5. Wash samples with $100 \%$ acetone.

During the first five minutes, change acetone until the solution becomes clear.

6. Incubate with the final change of acetone for 1 hour under the same conditions.

7. Mix equal volumes of $100 \%$ acetone and Technovit 8100 solution (Heraeus Kulzer, Wehrheim).

8. Incubate samples for 2 hours with this solution under previous conditions.

9. Perform infiltration and embedding using Technovit 8100 according to manufacturer's instructions.

10. Cut $4 \mu \mathrm{m}$-sections using a microtome, straighten them with warm sterile water on slides.

11. Store slides at $4^{\circ} \mathrm{C}$ until further use.

\subsubsection{Performing fluorescence in situ hybridization}

1. Sections should be rehydrated and prepared for hybridization as follows in order to improve permeability:

1.1. Wash slides with xylene $3 \times 10$ min.

1.2. Wash slides with $100 \%$ ethanol $3 \times 3$ min.

1.3. Wash slides with $90 \%$ ethanol $2 \times 3 \mathrm{~min}$.

1.4. Wash slides with $80 \%$ ethanol $2 \times 3 \mathrm{~min}$

1.5. Wash slides with $70 \%$ ethanol $1 \times 3 \mathrm{~min}$.

1.6. Wash slides with $50 \%$ ethanol $2 \times 3$ min.

1.7. Wash slides with double distilled water (DEPC) $2 \times 3 \mathrm{~min}$. 1.8. Incubate slides with $1 \mathrm{mg} / \mathrm{ml}$ Proteinase $\mathrm{K}$ in $0.2 \mathrm{M}$ Tris- $\mathrm{HCl}$ $(\mathrm{pH} 7.9)$ for $5 \mathrm{~min}$ at $37^{\circ} \mathrm{C}$ in a humid chamber.

1.9. Incubate slides with $1 \mathrm{mg} / \mathrm{ml}$ lysozyme in DEPC doubledestilled water for $15 \mathrm{~min}$ at $37^{\circ} \mathrm{C}$ in a humid chamber. 1.10. Wash slides three times with $1 X$ PBS.

2. Incubate slides with $100 \mathrm{ng}$ of each probe (specific bacterial $16 \mathrm{~S}$ rRNA-probe and universal eukaryotic $18 \mathrm{~S}$ rRNA-probe) diluted in $20 \mu \mathrm{l}$ of FISH-hybridization buffer (20\% (v/v) deionized formamide, $0.9 \mathrm{M} \mathrm{NaCl}, 20 \mathrm{mM}$ Tris- $\mathrm{HCl} \mathrm{pH} \mathrm{7.9,}$ $0.01 \%(\mathrm{~m} / \mathrm{v}) \mathrm{SDS})$

3. Cover with slip and transfer to a Corning chamber.

4. Dispense double-distilled water into the cavities of the chamber and close it.

5. Incubate in a humid chamber at $46^{\circ} \mathrm{C}$ from $4 \mathrm{~h}$ to overnight.

6. Carefully remove cover slip in $1 X$ PBS

7. Wash slides three times with $1 \mathrm{X}$ PBS.

8. Add $50 \mu \mathrm{l}$ of DAPI solution ( $1 \mu \mathrm{g} / \mathrm{ml}$ in methanol) to each slide.

9. Cover again.

10. Incubate at RT for $10 \mathrm{~min}$.

11. Remove cover slip in $1 \mathrm{X}$ PBS and wash slides three times with $1 \mathrm{X}$ PBS.

12. Mount slides with antifade reagent.

\section{Final remarks}

In the past decade, different basic issues related to American foulbrood have been addressed, including the reclassification of its aetiological agent (Genersch et al., 2006; Ashiralieva and Genersch, 2006), the development of methods for genotyping (Genersch and Otten, 2003; Alippi et al., 2004; Genersch et al., 2006; Antúnez et al., 2007) and the annotation of its genome sequence (Qin et al., 2006; Chan et al., 2011). The latter permitted the introduction of techniques for studying the bacterial transcriptome and proteome. Candidate reference genes and the methods to select them have been described in this paper. The availability of a protocol for heterologous expression of foreign proteins in $P$. larvae can be considered a great breakthrough 
in AFB research (Poppinga and Genersch, 2012). Nevertheless, we are only at the start of understanding the intimate relationship between $P$. larvae and its host. We hope that methods that are presented in this paper can help scientists to further explore the secrets of American foulbrood disease in honey bees.

\section{Acknowledgements}

We mourn the passing of Drs. Dieter De Koker who contributed to this chapter. Dieter was a talented PhD student at Ghent University. Our thoughts are with his family and friends. DCdG and LDS gratefully acknowledge the Research Foundation of Flanders (FWO-Vlaanderen; G.0163.11) for financial support.

\section{References}

AGRON, P G; MACHT, M; RADNEDGE, L; SKOWRONSKI, E W; MILLER, W; ANDERSEN, G L (2002) Use of subtractive hybridization for comprehensive surveys of prokaryotic genome differences. FEMS Microbiology Letters 211: 175-182.

http://dx.doi.org/10.1111/j.1574-6968.2002.tb11221.x

AKOPYANTS, N S; FRADKOV, A; DIATCHENKO, L; HILL, J E; SIEBERT, P D; LUKYANOV, S; SVERDLOV, E; BERG, D E (1998) PCR-based subtractive hybridization and differences in gene content among strains of Helicobacter pylori. Proceedings of the National Academy of Sciences USA 95 (22): 13108-13113. http://dx.doi.org/10.1073/pnas.95.22.13108

ALIPPI, A M (1991) A comparison of laboratory techniques for the detection of significant bacteria of the honey bee Apis mellifera $\mathrm{L}$. in Argentina. Journal of Apicultural Research 30(2): 75-80.

ALIPPI, A M (1995) Detection of Bacillus larvae spores in Argentinian honeys by using a semi-selective medium. Microbiologia SEM 11: 343-350.

ALIPPI, A M; AGUILAR, O M (1998a) Characterization of isolates of Paenibacillus larvae subsp. larvae from diverse geographical origin by the polymerase chain reaction and BOX primers. Journal of Invertebrate Pathology 72: 21-27.

http://dx.doi.org/10.1006/jipa.1998.4748

ALIPPI, A M; AGUILAR, O M (1998b). Unique fingerprints of Paenibacillus larvae subsp. larvae strains. Journal of Apicultural Research 37: 273-280.

ALIPPI, A M ; LOPEZ, A C; AGUILAR, O M (2002) Differentiation of Paenibacillus larvae subsp. larvae, the cause of American foulbrood of honey bees, by using PCR and restriction fragment analysis of genes encoding $16 \mathrm{~S}$ rRNA. Applied and Environmental Microbiology 68(7): 3655-3660.

http://dx.doi.org/10.1128/AEM.68.7.3655-3660.2002
ALIPPI, A M; LÓPEZ, A C; REYNALDI, F J; GRASSO, D H; AGUILAR, O M (2007) Evidence for plasmid-mediated tetracycline resistance in Paenibacillus larvae, the causal agent of a honey bee larval disease. Veterinary Microbiology 125: 290-303.

http://dx.doi.org/10.1016/j.vetmic.2007.05.018

ALIPPI, A M; REYNALDI, F J; LÓPEZ, A C; DE GIUSTI, M R; AGUILAR, O M (2004) Molecular epidemiology of Paenibacillus larvae larvae and incidence of American foulbrood in Argentinean honeys from Buenos Aires Province. Journal of Apicultural Research 43: 135-143. ALTSCHUL, S F; GISH, W; MILLER, W; MYERS, E W; LIPMAN, D J (1990) Basic local alignment search tool. Journal of Molecular Biology 215(3): 403-410. http://dx.doi.org/10.1006/jmbi.1990.9999 ALTSCHUL, S F; MADDEN, T L; SCHÄFFER, A A; ZHANG, J; ZHANG, Z; MILLER, W; LIPMAN, D J (1997) Gapped BLAST and PSI-BLAST: a new generation of protein database search programs. Nucleic Acids Research 25(17): 3389-3402. http://dx.doi.org/10.1093/nar/25.17.3389

ANTUNEZ, K; PICCINI, C; CASTRO-SOWINSKI, S; ROSADO, A S; SELDIN, L; ZUNINO, P (2007) Phenotypic and genotypic characterization of Paenibacillus larvae isolates. Veterinary Microbiology 124: 178-183.

http://dx.doi.org/10.1016/j.vetmic.2007.04.012

ASHIRALIEVA, A; GENERSCH, E (2006) Reclassification, genotypes and virulence of Paenibacillus larvae, the etiological agent of American foulbrood in honey bees - a review. Apidologie 37(4): 411-420. http://dx.doi.org/10.1051/apido:2006028

BÜCHLER, R; ANDONOV, S; BIENEFELD, K; COSTA, C; HATJINA, F; KEZIC, N; KRYGER, P; SPIVAK, M; UZUNOV, A; WILDE, J (2013) Standard methods for rearing and selection of Apis mellifera queens. In V Dietemann; J D Ellis; P Neumann (Eds) The COLOSS BEEBOOK, Volume I: standard methods for Apis mellifera research. Journal of Apicultural Research 52(1): http://dx.doi.org/10.3896/IBRA.1.52.1.07

CHAN, Q W T; MELATHOPOULOS, A P; PERNAL, S F; FOSTER, L J (2009) The innate immune and systemic response in honey bees to a bacterial pathogen, Paenibacillus larvae. BMC Genomics 10: 387. http://dx.doi.org/10.1186/1471-2164-10-387

CHAN, Q W T; CORNMAN, R S; BIROL, I; LIAO, N Y; CHAN, S K; DOCKING, T R; JACKMAN, S D; TAYLOR, G A; JONES, S J M; DE GRAAF, D C; EVANS, J D; FOSTER, L J (2011) Updated genome assembly and annotation of Paenibacillus larvae, the agent of American foulbrood disease of honey bees. BMC Genomics 12: 450. http://dx.doi.org/10.1186/1471-2164-12-450

DE GRAAF, D C; ALIPPI, A M; BROWN, M; EVANS, J D; FELDLAUFER, M; GREGORC, A; HORNITZKY, M A Z; PERNAL, S F; SCHUCH, D M T; TITERA, D; TOMKIES, V; RITTER, W (2006a) Diagnosis of American foulbrood in honey bees: a synthesis and proposed analytical protocols. Letters in Applied Microbiology 43: 583-590. http://dx.doi.org/10.1111/j.1472-765X.2006.02057.x 
DE GRAAF, D C; DE VOS, P; HEYNDRICKX, M; VAN TRAPPEN, S; PEIREN, N; JACOBS, F J (2006b) Identification of Paenibacillus larvae to the subspecies level: an obstacle for AFB diagnosis. Journal of Invertebrate Pathology 91(2): 115-123.

http://dx.doi.org/10.1016/j.jip.2005.10.010

DE GRAAF, D C; BRUNAIN, M; JACOBS, F J (2008) Implementation of quality control and biosafety measurements in the diagnosis of honey bee diseases. Journal of Apicultural Research 47(2): 151-153.

DELAPLANE, K S; VAN DER STEEN, J; GUZMAN, E (2013) Standard methods for estimating strength parameters of Apis mellifera colonies. In V Dietemann; J D Ellis; P Neumann (Eds) The COLOSS BEEBOOK, Volume I: standard methods for Apis mellifera research. Journal of Apicultural Research 52(1):

http://dx.doi.org/10.3896/IBRA.1.52.1.03

DIATCHENKO, L; LAU, Y F; CAMPBELL, A P; CHENCHIK, A; MOQADAM, F; HUANG, B; LUKYANOV, S; LUKYANOV, K; SVERDLOV, E D; SIEBERT, P D (1996) Suppression subtractive hybridization: a method for generating differentially regulated or tissue-specific cDNA probes and libraries. Proceedings of the National Academy of Science USA 93(12): 6025-6030. http://dx.doi.org/10.1073/pnas.93.12.6025

DINGMAN, D W (1983) Bacillus larvae: parameters involved with sporulation and characteristics of two bacteriophages. PhD thesis, University of Iowa, Iowa City, Iowa, USA.

DINGMAN, D W; STAHLY, D P (1983) Medium promoting sporulation of Bacillus larvae and metabolism of medium components. Applied and Environmental Microbiology 46: 860-869.

DINGMAN, D W; STAHLY, D P (1984) Protection of Bacillus larvae from oxygen toxicity with emphasis on the role of catalase. Applied and Environmental Microbiology 47: 1228-1237.

DOBBELAERE, W; DE GRAAF, D C ; PEETERS, J E; JACOBS, F J (2001) Development of a fast and reliable diagnostic method for American foulbrood disease (Paenibacillus larvae subsp. larvae) using a 16S rRNA gene based PCR. Apidologie 32: 363-370.

DJORDJEVIC, S; HO-SHON, M; HORNITZKY, M A Z (1994) DNA restriction endonuclease profiles and typing of geographically diverse isolates of Bacillus larvae. Journal of Apicultural Research 33(2): 95-103.

DUNN, A K; HANDELSMAN; J (1999) A vector for promoter trapping in Bacillus cereus. Gene 226: 297-305. http://dx.doi.org/10.1016/S0378-1119(98)00544-7

EVANS, J D; PETTIS, J S (2005) Colony-level impacts of immune responsiveness in honey bees, Apis mellifera. Evolution 59: 22702274. http://dx.doi.org/10.1554/05-060.1

FORNER, F; FOSTER, L J; TOPPO, S (2007) Mass spectrometry data analysis in the proteomics era. Current Bioinformatics 2(14): 63-93. http://dx.doi.org/10.2174/157489307779314285
FORSGREN, E; STEVANOVIC, J; FRIES, I (2008) Variability in germination and in temperature and storage resistance among Paenibacillus larvae genotypes. Veterinary Microbiology 129: 342-349. http://dx.doi.org/10.1016/j.vetmic.2007.12.001

FÜNFHAUS, A; ASHIRALIEVA, A; BORRISS, R; GENERSCH, E (2009) Use of suppression subtractive hybridization to identify genetic differences between differentially virulent genotypes of Paenibacillus larvae, the etiological agent of American foulbrood of honey bees. Environmental Microbiology Reports 1(4): 240-250. http://dx.doi.org/10.1111/j.1758-2229.2009.00039.x

FÜNFHAUS, A; GENERSCH, E (2012) Proteome analysis of Paenibacillus larvae reveals the existence of a putative S-layer protein. Environmental Microbiology Reports 4: 194-202. http://dx.doi.org/10.1111/j.1758-2229.2011.00320.x

GENERSCH, E; OTTEN, C (2003) The use of repetitive element PCR fingerprinting (rep-PCR) for genetic subtyping of German field isolates of Paenibacillus larvae subsp. larvae. Apidologie 34: 195206. http://dx.doi.org/10.1051/apido:2003025

GENERSCH, E; ASHIRALIEVA, A; FRIES, I (2005) Strain- and genotype -specific differences in virulence of Paenibacillus larvae subsp. larvae, a bacterial pathogen causing American foulbrood disease in honey bees. Applied and Environmental Microbiology 71: 75517555. http://dx.doi.org/10.1128/AEM.71.11.7551-7555.2005

GENERSCH, E; FORSGREN, E; PENTIKÄINEN, J; ASHIRALIEVA, A; RAUCH, S; KILWINSKI, J; FRIES, I (2006) Reclassification of Paenibacillus larvae subsp. pulvifaciens and Paenibacillus larvae subsp. larvae as Paenibacillus larvae without subspecies differentiation. International Journal of Systematic and Evolutionary Microbiology 56(3): 501-511. http://dx.doi.org/10.1099/ijs.0.63928-0

GENERSCH, E (2010) American foulbrood in honey bees and its causative agent, Paenibacillus larvae. Journal of Invertebrate Pathology 103 Suppl. 1: 10-19. http://dx.doi.org/10.1016/j.jip.2009.06.015

GOCHNAUER, T A (1973) Growth, protease formation, and sporulation of Bacillus larvae in aerated broth culture. Journal of Invertebrate Pathology 22: 251-257.

GORDON, R E; HAYNES, W C; PANG, C H (1973) The genus Bacillus. Agriculture handbook no. 427, Agricultural Research Service, US Dept. of Agriculture, Washington, DC, USA.

GOVAN, V A; ALLSOPP, M H; DAVISON, S (1999) A PCR detection method for rapid identification of Paenibacillus larvae. Applied and Environmental Microbiology 65: 2243-2245.

HACKER, J; BLUM-OEHLER, G; MUHLDORFER, I; TSCHAPE, H (1997) Pathogenicity islands of virulent bacteria: structure, function and impact on microbial evolution. Molecular Microbiology 23: 10891097. http://dx.doi.org/10.1046/j.1365-2958.1997.3101672.x 
HARTFELDER, K; GENTILE BITONDI, M M; BRENT, C; GUIDUGLILAZZARINI, K R; SIMÕES, Z L P; STABENTHEINER, A; DONATO TANAKA, É; WANG, Y (2013) Standard methods for physiology and biochemistry research in Apis mellifera. In V Dietemann; J D Ellis; P Neumann (Eds) The COLOSS BEEBOOK, Volume I: standard methods for Apis mellifera research. Journal of Apicultural Research 52(1): http://dx.doi.org/10.3896/IBRA.1.52.1.06

HAYNES, W C; ST JULIAN, G; SHEKLETON, M C; HALL, H H; TASHIRO, H (1961) Preservation of infectious milky disease bacteria by lyophilization. Journal of Insect Pathology 3: 55-61. HELLEMANS, J; MORTIER, G; DE PAEPE, A; SPELEMAN, F;

VANDESOMPELE, J (2007) qBase relative quantification framework and software for management and automated analysis of real-time quantitative PCR data. Genome Biology 8: R19.

http://dx.doi.org/10.1186/gb-2007-8-2-r19

HITCHCOCK, J D; MOFFETT, J O; LACKETT, J J; ELLIOTT, J R (1970) Tylosin for control of American foulbrood disease in honey bees. Journal of Economic Entomology 63: 204-207.

HORNITZKY, M A Z; CLARK, S (1991) Culture of Bacillus larvae from bulk honey samples for the detection of American foulbrood. Journal of Apicultural Research 30: 13-16.

HORNITZKY, M A Z; DJORDEVIC, S (1992). Sodium dodecyl sulphate polyacrylamide profiles and Western blots of Bacillus larvae. Journal of Apicultural Research 31(1): 47-49.

HORNITZKY, M A Z; KARLOVSKIS, S (1989) A culture technique for the detection of Bacillus larvae in honey bees. Journal of Apicultural Research 28(2): 118-120.

HORNITZKY, M A Z; NICHOLLS, P J (1993) J-medium is superior to sheep blood agar and brain heart infusion agar for the isolation of Bacillus larvae from honey samples. Journal of Apicultural Research 32: 51-52.

HUMPHERY-SMITH, I; CORDWELL, S J; BLACKSTOCK, W P (1997)

Proteome research: Complementarity and limitations with respect to the RNA and DNA worlds. Electrophoresis 18(8): 1217-1242. http://dx.doi.org/10.1002/elps.1150180804

ITZKOVITZ, S; VAN OUDENAARDEN, A (2011) Validating transcripts with probes and imaging technology. Nature Methods 8: S12-S19. http://dx.doi.org/10.1038/NMETH.1573

JANKE, B; DOBRINDT, U; HACKER, J; BLUM-OEHLER, G (2001) A subtractive hybridization analysis of genomic differences between the uropathogenic $E$. coli strain 536 and the $E$. coli $\mathrm{K}-12$ strain MG1655. FEMS Microbiology Letters 199: 61-66.

http://dx.doi.org/10.1111/j.1574-6968.2001.tb10651.x

KILWINSKI, J; PETERS, M; ASHIRALIEVA, A; GENERSCH, E (2004) Proposal to reclassify Paenibacillus larvae subsp. pulvifaciens DSM 3615 (ATCC 49843) as Paenibacillus larvae subsp. larvae. Results of a comparative biochemical and genetic study. Veterinary Microbiology. 104: 31-42.

http://dx.doi.org/10.1016/j.vetmic.2004.08.001
KLOSE, J (1975) Protein mapping by combined isoelectric focusing and electrophoresis of mouse tissues. A novel approach to testing for induced point mutations in mammals. Humangenetik 26(3): 231-243.

LONCARIC, I; DERAKHSHIFAR, I; OBERLERCHNER, J T; KÃGLBERGER, H; MOOSBECKHOFER, R (2009) Genetic diversity among isolates of Paenibacillus larvae from Austria. Journal of Invertebrate Pathology 100(1): 44-46.

http://dx.doi.org/10.1016/j.jip.2008.09.003

MOTER, A; LEIST, G; RUDOLPH, R; SCHRANK, K; CHOI, B K; WAGNER, M; GÖBEL, U B (1998) Fluorescence in situ hybridization shows spatial distribution of as yet uncultured treponemes in biopsies from digital dermatitis lesions. Microbiology 144(9): 2459-2467.

MURRAY, K D; ARONSTEIN, K A (2006) Oxytetracycline-resistance in the honey bee pathogen Paenibacillus larvae is encoded on novel plasmid pMA67. Journal of Apicultural Research. 45: 207-214.

MURRAY, K D; ARONSTEIN, K A; DE LEÓN, J H (2007) Analysis of pMA67, a predicted rolling-circle replicating, mobilizable, tetracycline-resistance plasmid from the honey bee pathogen, Paenibacillus larvae. Plasmid 58: 89-100. http://dx.doi.org/10.1016/j.plasmid.2007.02.001

MURRAY, K D; ARONSTEIN, K A (2008) Transformation of the Grampositive honey bee pathogen, Paenibacillus larvae, by electroporation. Journal of Microbiological Methods 75: 325-328. http://dx.doi.org/10.1016/j.mimet.2008.07.007

NEUENDORF, S; HEDTKE, K; TANGEN, G; GENERSCH, E (2004) Biochemical characterization of different genotypes of Paenibacillus larvae subsp. larvae, a honey bee bacterial pathogen. Microbiology 150(7): 2381-2390. http://dx.doi.org/10.1099/mic.0.27125-0

NORDSTRÖM, S; FRIES, I (1995) A comparison of media and cultural conditions for identification of Bacillus larvae in honey. Journal of Apicultural Research 34: 97-103.

O'FARRELL, P H (1975) High resolution two-dimensional electrophoresis of proteins. Journal of Biological Chemistry 250 (10): 4007-4021.

OIE (2008) Chapter 2.2.2. American foulbrood. In OIE Manual of Diagnostic Tests and Vaccines for Terrestrial Animals (mammals, birds and bees), vol. 1 (Sixth Edition). OIE; Paris, France. pp 395404.

OIE (2011) Chapter 9.2. American foulbrood. In OIE Terrestrial Animal Health Code, vol. 2 (Twentieth Edition). OIE; Paris, France. pp 504-506.

OLIVE, D M; BEAN, P (1999) Principles and applications of methods for DNA-based typing of microbial organisms. Journal of Clinical Microbiology 37(6): 1661-1669.

ONG, S E; FOSTER, L J; MANN, M (2003) Mass spectrometric-based approaches in quantitative proteomics. Methods. 29(2): 124-30. http://dx.doi.org/10.1016/S1046-2023(02)00303-1 
PANDEY, A; MANN, M (2000) Proteomics to study genes and genomes. Nature 405(6788): 837-846.

PETERS, M; KILWINSKI, J; BERINGHOFF, A; RECKLING, D;

GENERSCH, E (2006) American foulbrood of the honey bee:

Occurrence and distribution of different genotypes of Paenibacillus larvae in the administrative district of Arnsberg (North RhineWestphalia). Journal of Veterinary Medicine 53(2): 100-104. http://dx.doi.org/10.1111/j.1439-0450.2006.00920.x

PIRK, C W W; DE MIRANDA, J R; FRIES, I; KRAMER, M; PAXTON, R; MURRAY, T; NAZZI, F; SHUTLER, D; VAN DER STEEN, J J M; VAN DOOREMALEN, C (2013) Statistical guidelines for Apis mellifera research. In V Dietemann; J D Ellis; P Neumann (Eds) The COLOSS BEEBOOK, Volume I: standard methods for Apis mellifera research. Journal of Apicultural Research 52(4):

http://dx.doi.org/10.3896/IBRA.1.52.4.13

POPPINGA, L; GENERSCH, E (2012) Heterologous expression of green fluorescent protein in Paenibacillus larvae, the causative agent of American foulbrood of honey bees. Journal of Applied Microbiology 112: 430-435. http://dx.doi.org/10.1111/j.1365-2672.2011.05214.x QIN, $X$; EVANS, J D; ARONSTEIN, K A; MURRAY, K D; WEINSTOCK, G M (2006) Genome sequences of the honey bee pathogens Paenibacillus larvae and Ascosphaera apis. Insect Molecular Biology 15(5): 715-718. http://dx.doi.org/10.1111/j.1365-2583.2006.00694.x

RAPPSILBER, J; MANN, M; ISHIHAMA, Y (2007) Protocol for micropurification, enrichment, pre-fractionation and storage of peptides for proteomics using StageTips. Nature Protocols 2(8): 1896-906. http://dx.doi.org/10.1038/nprot.2007.261

RAUCH, S; ASHIRALIEVA, A; HEDTKE, K; GENERSCH, E (2009) Negative correlation between individual-insect-level virulence and colony-level virulence of Paenibacillus larvae, the etiological agent of American foulbrood of honey bees. Applied and Environmental Microbiology 75: 3344-3347.

http://dx.doi.org/10.1128/AEM.02839-08

RECKSEIDLER, S L; DESHAZER, D; SOKOL, P A; WOODS, D E (2001)

Detection of bacterial virulence genes by subtractive hybridization: identification of capsular polysaccharide of Burkholderia pseudomallei as a major virulence determinant. Infection and Immunity 69: 34-44. http://dx.doi.org/10.1128/IAI.69.1.34-44.2001

SCHUCH, D M T; MADDEN, R H; SATTLER, A (2001) An improved method for the detection and presumptive identification of Paenibacillus larvae subsp larvae spores in honey. Journal of Apicultural Research 40: 59-64.

SHIMANUKI, H; KNOX, D A (2000) Diagnosis of honey bee diseases. USDA Agricultural Handbook No. H-690, Washington DC, USA. 61 pp. SIEBERT, P D; CHENCHIK, A; KELLOGG, D E; LUKYANOV, K A; LUKYANOV, S A (1995) An improved PCR method for walking in uncloned genomic DNA. Nucleic Acids Research 23: 1087-1088. http://dx.doi.org/10.1093/nar/23.6.1087
SPIVAK, M; REUTER, G S (2001) Resistance to American foulbrood disease by honey bee colonies, Apis mellifera, bred for hygienic behaviour. Apidologie 32: 555-565.

STEINKRAUS, K H; MORSE, R A (1996) Media for the detection of Bacillus larvae spores in honey. Acta Biotechnologica 16: 57-64.

TATUSOV, R L; KOONIN, E V; LIPMAN, D J (1997) A genomic perspective on protein families. Science 278(5338): 631-637. http://dx.doi.org/10.1126/science.278.5338.631

TATUSOV, R L; FEDOROVA, N D; JACKSON, J D; JACOBS, A R; KIRYUTIN, B; KOONIN, E V; KRYLOV, D M; MAZUMDER, R; MEKHEDOV, S L; NIKOLSKAYA, A N; RAO, B S; SMIRNOV, S; SVERDLOV, A V; VASUDEVAN, S; WOLF, Y I; YIN, J J; NATALE, D A (2003) The COG database: an updated version includes eukaryotes. BMC Bioinformatics 4: 41. http://dx.doi.org/10.1186/1471-2105-4-41

THOMAS, S R; ELKINTON, J S (2004) Pathogenicity and virulence. Journal of Invertebrate Pathology 85: 146-151. http://dx.doi.org/10.1016/j.jip.2004.01.006

TORTO, B; CARROLL, M J; DUEHL, A; FOMBONG, A T; NAZZI, F, GOZANSKY, K T; SOROKER, V, TEAL, P E A (2013) Standard methods for chemical ecology research in Apis mellifera. In $V$ Dietemann; J D Ellis; P Neumann (Eds) The COLOSS BEEBOOK, Volume I: standard methods for Apis mellifera research. Journal of Apicultural Research 52(4): http://dx.doi.org/10.3896/IBRA.1.52.4.06

TSIEN, R Y (1998) The green fluorescent protein. Annual Review of Biochemistry 67: 509-44.

http://dx.doi.org/10.1146/annurev.biochem.67.1.509

UNTERGASSER, A; NIJVEEN, H; RAO, X; BISSELING, T; GEURTS, R; LEUNISSEN, J A M (2007) Primer3plus, an enhanced web interface to primer3. Nucleic Acids Research 35: W71-W74. http://dx.doi.org/10.1093/nar/gkm306

VANDESOMPELE, J; DE PRETER, K; PATTYN, F; POPPE, B; VAN ROY, N; DE PAEPE, A; SPELEMAN, F (2002) Accurate normalization of realtime quantitative RT-PCR data by geometric averaging of multiple internal control genes. Genome Biology 3(7): 0034.1. http://dx.doi.org/10.1186/gb-2002-3-7-research0034

VERSALOVIC, J; SCHNEIDER, M; DE BRUIJN, F J; LUPSKI, J R (1994). Genomic fingerprinting of bacteria using repetitive sequencebased polymerase chain reaction. Methods in Molecular and Cellular Biology 5: 25-40.

WU, X Y; CHIN, J; GHALAYINI, A; HORNITZKY, M A Z (2005) Pulsedfield gel electrophoresis typing and oxytetracycline sensitivity of Paenibacillus larvae subsp. larvae isolates of Australian origin and those recovered from honey imported from Argentina. Journal of Apicultural Research 44: 87-92. 
YUE, D; NORDHOFF, M; WIELER, L H; GENERSCH, E (2008) Fluorescence in situ hybridization (FISH) analysis of the interactions between honey bee larvae and Paenibacillus larvae, the causative agent of American foulbrood of honey bees (Apis mellifera). Environmental Microbiology 10: 1612-1620. http://dx.doi.org/10.1111/j.1462-2920.2008.01579.x
ZHANG, Y L; ONG, C T; LEUNG, K Y (2000) Molecular analysis of genetic differences between virulent and avirulent strains of Aeromonas hydrophila isolated from diseased fish. Microbiology 146: 999-1009.

ZUKER, M (2003) Mfold web server for nucleic acid folding and hybridization prediction. Nucleic Acids Research 31: 3406-3415. http://dx.doi.org/10.1093/nar/gkg595 
